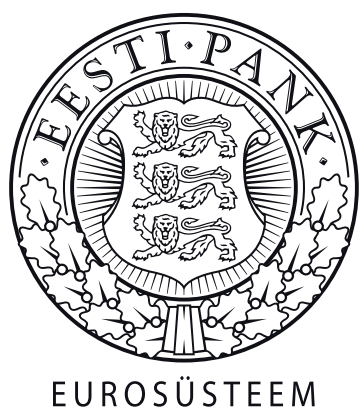

Working Paper Series 6/2017

CREDIT PRICES

VS. CREDIT QUANTITIES

AS PREDICTORS OF

ECONOMIC ACTIVITY

IN EUROPE: WHICH TELL

A BEITER STORY?

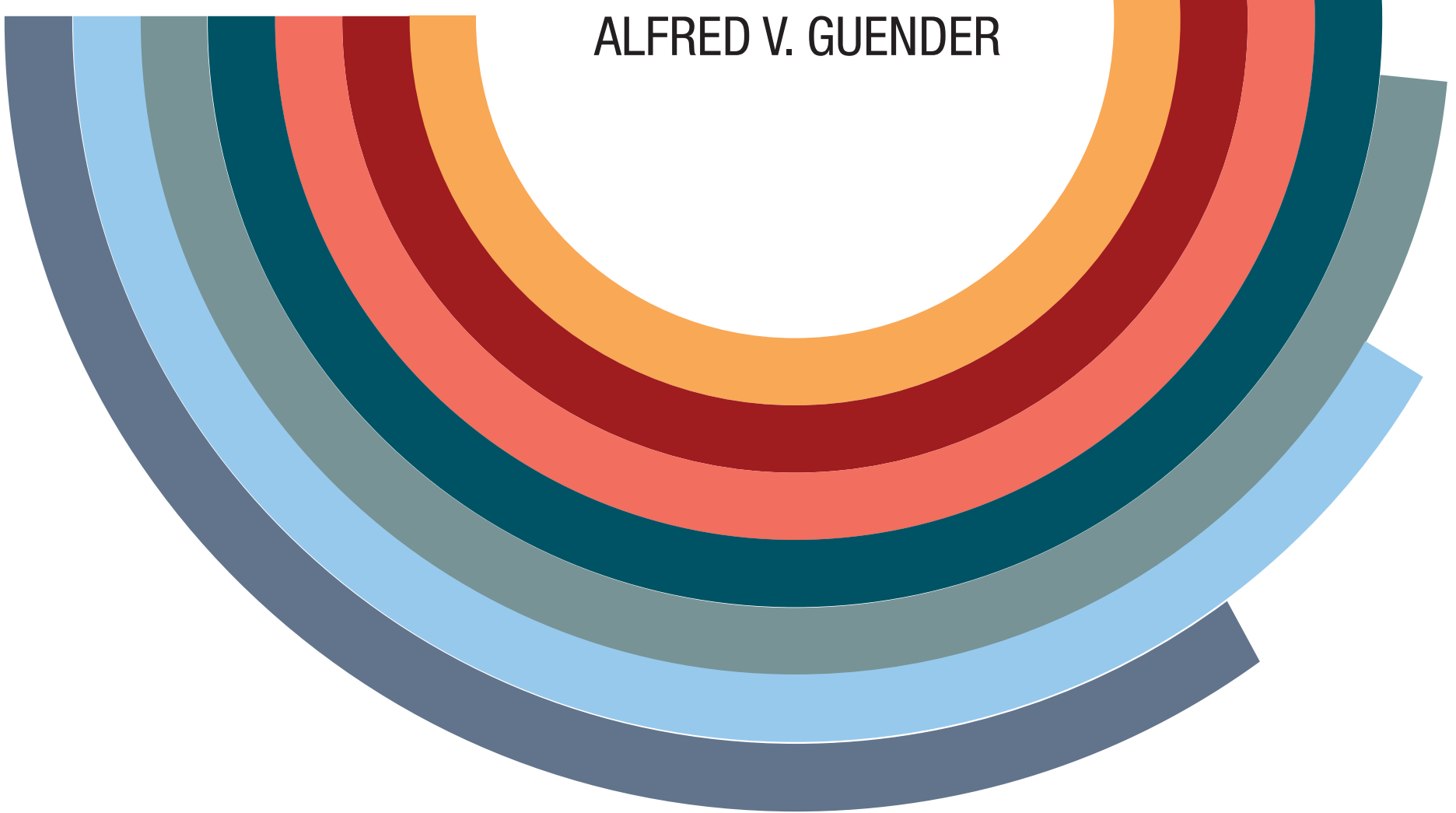


The Working Paper is available on the Eesti Pank web site at:

http://www.eestipank.ee/en/publications/series/working-papers

For information about subscription call: +372 668 0998; Fax: +372 6680954

e-mail: publications@eestipank.ee

DOI: $10.23656 / 25045520 / 62017 / 0144$

ISBN 978-9949-606-10-8 (print)

ISBN 978-9949-606-11-5 (pdf)

Eesti Pank. Working Paper Series, ISSN 1406-7161; 6/2017 (hard copy)

Eesti Pank. Working Paper Series, ISSN 2504-5520; 6/2017 (pdf) 


\title{
Credit Prices vs. Credit Quantities as Predictors of Economic Activity in Europe: Which Tell a Better Story?
}

\author{
Alfred V. Guender
}

\begin{abstract}
This paper examines the role of credit providers in the EMU and assesses the effects of credit spreads and credit quantities on economic activity. Movements in credit spreads are far more successful than movements in the external finance mix in predicting near-term changes in real economic activity in ten EMU countries. However, the forecasting performance of the three credit spreads evaluated in this paper is uneven. A risk premium extracted from individual corporate bond yields predicts three measures of economic activity fairly well in Germany and Southern Europe. Two other credit spreads, the 'spread' and the 'ECB-spread', have predictive power for some measures of economic activity but they fail to predict consistently across either a range of economic indicators or countries.
\end{abstract}

JEL Codes: E3, E4, G1

Keywords: credit spreads, finance mix, bank vs open market debt, economic activity, financial crises

The views expressed are those of the author and do not necessarily represent the official views of Eesti Pank or the Eurosystem.

\footnotetext{
"Corresponding author's e-mail address: Alfred.Guender@canterbury.ac.nz

This paper was finalized while Alfred V. Guender was a visiting researcher at the Bank of Estonia. He is grateful for the hospitality and the research support of the Bank of Estonia in Tallinn where this research project began. His sincere thanks go to the members of the Economics and Research Department of the Bank as well as the seminar participants for providing feedback at the initial stage of the project. He is particularly indebted to Dmitri Kulikov and his colleague Kuntal Das for thoughtful discussions about statistical concepts and econometric issues and an anonymous BofE referee for making helpful suggestions.
} 


\section{Non-technical summary}

This paper assesses aggregate credit conditions and their potential ramifications for aggregate economic activity in ten member countries of the euro area over the period 2003-2016. The countries included in the study are Austria, Belgium, Finland, France, Germany, Greece, Italy, the Netherlands, Portugal and Spain. The sample period begins a few years after the formation of the EMU, covers the Global Financial Crisis and the European Debt Crisis, and ends at a time when relative stability returns to financial markets.

At the heart of the paper lies a simple question: do movements in the prices of credit provide more information about future economic activity than changes in the quantity of credit outstanding do? To answer this question, the price and sources of credit must first be defined in the context of a simple theoretical model that follows Adrian, Colla and Shin (2013).

There are two sources of credit for a typical firm as a borrower. The first source of credit is a risk-neutral, perfectly competitive bank that pools the savings of households in the form of demand deposits. Along with the bank's equity base these demand deposits fund the loan portfolio. The bank charges the going lending rate on loans and pays the riskless rate on deposits. Loans are not guaranteed to be paid back. There is an element of risk in that the firm borrowing funds may invest in projects that fail. To compensate for this risk, the bank charges a risk premium. The second source of credit is direct borrowing by firms from risk-averse households. To access this source of credit, firms issue bonds at the going rate. The differences in the attitudes to risk of banks and households matter. If there is a very low probability of a project defaulting, the sole criterion that matters in a bank's decision of whether to offer credit of a certain size is the probability of default; this is not so for households who operate in a risk-return trade-off environment and are willing to accept greater volatility of returns in exchange for higher expected returns.

Starting from a low probability of the project defaulting, suppose this probability increases somewhat. Banks react by cutting their loan portfolio, thus forcing up the lending rate. This increase in the interest rate charged on borrowed funds induces households to provide more credit to firms despite the higher risk. There is thus a substitution of bond finance for bankfinanced credit against the backdrop of a rising risk premium. All told, there are offsetting movements in the quantity of the two sources of credit, but there is an unambiguous increase in the risk premium and hence in the cost of obtaining credit.

The predictions of the model for movements in the price and the quantity of aggregate credit are verified empirically. The price of credit is defined in relative terms as the spread between the cost of borrowing for non-financial corporations from Monetary Financial Institutions less a low risk money market rate (Spread) or the ECB-Spread, which is the difference between the cost of taking out new loans and the swap rate. Towards the end of the paper we also introduce a measure of a bond yield spread that captures the risk premium in the bond market (GZ-Spread). The aggregate quantity of credit outstanding is measured as the sum of bank loans issued by MFIs and the volume of securities (bonds) issued by nonfinancial corporations. To capture the changing composition of total credit outstanding, we calculate the ratio of bank loans to total credit and call it the 'Finance Mix'. 
The variables that are thought to provide information about changes in aggregate credit conditions through movements in relative price (Spread, ECB-Spread, and GZ-Spread) or changes in the composition of credit quantities outstanding (Finance Mix) appear in a simple forecasting equation. An aggregate economic indicator (Industrial Production, the Rate of Unemployment, Retail Sales, and Turnover of Capital Goods) is regressed on its own lags, lags of one of the spreads, and lags of the finance mix variable to gauge the relative predictive ability of the price-based and quantity-based financial information variables. Two tests with different sign restrictions are employed to measure predictive ability. The first test is a standard F-test that measures the exclusion restriction that all lags of the financial information variable can be omitted from the estimated specification, meaning that the financial variable has no predictive content for aggregate activity. The second test uses a t-test to check whether the sum of the estimated coefficients on the lags of the financial information variable accords with the predictions of the underlying model (sign test).

The empirical results show that credit spreads provide a more reliable signal about nearterm economic activity than the composition of external finance does. A presumed link between changes in the composition of external finance and changes in real economic activity appears not to exist. These findings tend to support Adrian, Colla and Shin's basic contention that movements in risk premiums rather than contraction in the total quantity of credit lie behind changes in economic activity.

Overall the findings suggest, however, that the forecasting performance of credit spreads over a short horizon in the ten EMU member states is rather spotty. This assessment is based on the uneven performance of the credit spreads. The Spread is arguably a better predictor of real economic activity than the ECB-Spread. Even so, the Spread fails to predict consistently either across a range of monthly economic indicators or across countries. The strongest evidence in favour of the predictive ability of credit spreads comes from the corporate bond market. The GZ-Spread, a risk premium extracted from corporate bond yields, predicts Industrial Production, Retail Sales, and Turnover of Capital Goods fairly well in Southern Europe and Germany.

Examining developments in credit markets in the euro area over the past 15 years leads to the conclusion that these markets have evolved unevenly. In the Netherlands, and particularly in Finland and France, the bond market was an important secondary source of credit long before the Global Financial Crisis. By contrast, in Austria, Belgium, Germany, Italy and Portugal, the bond market's relative share of the credit market gradually increased over the sample period, while it remained very small in Greece and Spain. The empirical study finds mixed evidence for the substitution hypothesis of bond finance for bank credit during recessions in the euro area. While there is no evidence at all for it during the first recession, there is selective evidence that bond issuance expanded and bank loans contracted during the second recession particularly in France and Italy and to a lesser extent in Greece and Spain. On balance, the size of the financial sector is not tied to the near-term forecasting performance of financial indicators. 


\section{Contents}

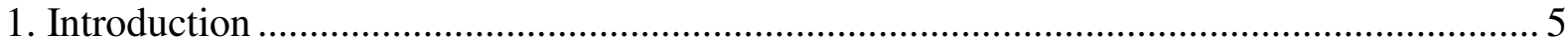

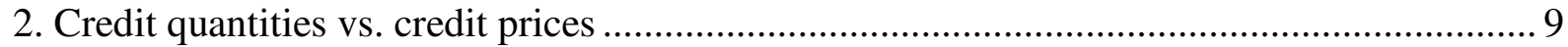

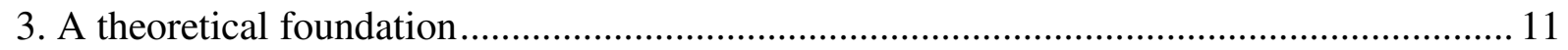

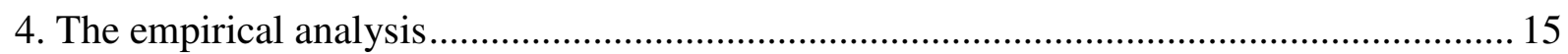

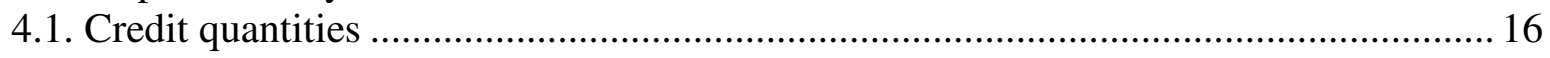

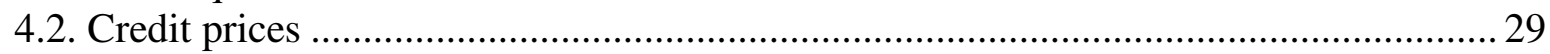

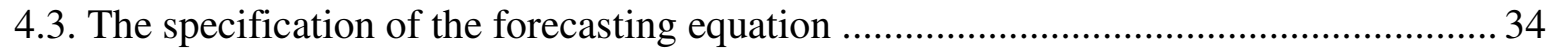

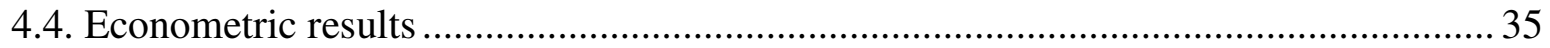

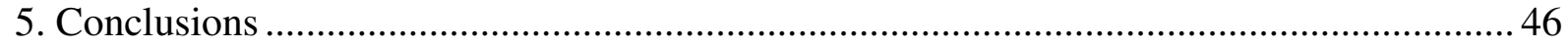

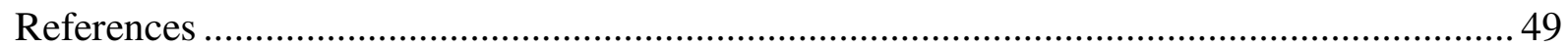




\section{Introduction}

Continental Europe is still battling the adverse consequences of the Global Financial Crisis and the ensuing Sovereign Debt Crisis. More than three years after the end of the last euro area-wide recession, quite a few member countries of the EMU had still not achieved precrisis levels of output and were struggling to reflate their economies. ${ }^{1}$ The lasting impact of both crises and the slow recovery from them have led many commentators to believe that the root cause of the economic downturns in 2008 and 2011 is different from those that triggered recessions in the 1970s, 1980s or 1990s. ${ }^{2}$ Earlier recessions were caused by supply shocks and the resulting monetary policy decisions or outright monetary policy shocks. The catalysts responsible for the two most recent recessions were, however, financial in nature and intrinsically linked to fragile asset markets, excessive leverage by financial institutions and households, and unsustainable fiscal policies. ${ }^{3}$

The recent upheavals in financial markets again turn the spotlight on the crucial role of credit for real economic activity. Two issues loom large in analysing the behaviour of credit markets as financial or economic conditions change, and these are the identification of shifts in credit outstanding and the causes underlying changes in the composition of credit. When credit shrinks in a financial crisis, the production of goods and services follows suit. ${ }^{4}$ While this process is well understood, there remains the important question of whether the decrease in aggregate credit is due to a reduction of the supply of credit, a fall in the demand for credit, or a combination of both. The other issue pertains to the behaviour of credit providers as the economic outlook changes. In a recent paper Adrian, Colla, and Shin (2013) (ACS) examine

\footnotetext{
${ }^{1}$ Excluding countries that joined the currency union recently, nominal GDP was lower in Finland, Greece, Italy, Portugal, and Spain in 2015 than in 2007.

${ }^{2}$ Much ink has been spilled elaborating on the causes of recessions. Taking a long-term perspective, Reinhart and Rogoff (2009) aver that recessions triggered by financial crises tend to be severe and long-lasting. Claessens, Kose, and Terrones (2009) observe that recessions accompanied by credit crunches in OECD countries are longer-lasting and deeper than conventional recessions. Cecchetti et al. (2009) examine the length, depth, and output loss of contractions in the aftermath of banking crises in 35 advanced and developing countries over the 1980-2007 period. They argue that banking crises are inherently diverse and their flow-on effects are instrumental in determining output loss. For instance, a banking crisis giving rise to a currency crisis results in higher output loss than a banking crisis leading to sovereign debt default. The view that financial crises are long-lasting and lead to large output losses is challenged by Romer and Romer (2015). Their narrative approach, based on a single contemporaneous information source, produces a measure of financial distress that ranges from a mere credit disruption to an extreme crisis. Examining the impact of financial distress on economic activity in OECD countries over a 40-year period before the Global Financial Crisis, Romer and Romer find it to be rather weak and transitory. Schularick and Taylor (2012) investigate the dynamics of money, credit, and the macroeconomy from 1870 to 2008 in 14 advanced countries. They conclude that monitoring the behaviour of credit aggregates is helpful in assessing the likelihood of future financial crises.

${ }^{3}$ Focusing on the changing characteristics of the financial sector and their consequences for the transmission process of monetary policy, Borio and Zhu (2012) emphasize that a low interest rate environment promotes greater risk taking by banks. In the face of financing and liquidity constraints, a potent risk-taking channel of monetary policy may destabilize the financial sector and ultimately cause substantial loss of output and employment. Dell' Ariccia et al. (2014) provide an analytical exposition of monitoring and risk taking by banks. The effects of changes in capital regulation on bank behaviour are described in VanHoose (2007).

${ }^{4}$ Schularick and Taylor (2012) find that the cumulative losses of real output and investment (relative to trend) following financial crises in the post-WW2 period (1948-2008) amounted to 7.9 and 25.7 per cent, respectively. The losses are measured over a five-year period. Both bank assets and bank loans decreased considerably as well, assets by 14.4 per cent and loans by 25.8 per cent, while narrow money remained static and broad money decreased slightly.
} 
the behaviour of credit providers - banks and the bond market - against the backdrop of worsening economic conditions. In their model bank loans or bonds are the two sources of credit that finance spending by firms. Importantly, direct credit is a substitute for intermediated credit in much the same way as in Kashyap, Stein and Wilcox (1993). Expecting the economic outlook to worsen in the near term, profit-maximizing risk-neutral banks cut their loan portfolio, thereby forcing companies to turn to the bond market to finance their expenditure. This is not a seamless or costless process. To induce risk-averse households to absorb the newly issued bonds, the bond-issuing firms have to offer a higher risk premium. The rise in the risk premium raises the cost of borrowing, resulting in a partial reduction in the demand for funding. Their model-based analysis leads ACS to put forth the following propositions. First, there is an unambiguous widening of the gap between the cost of borrowing and the riskless interest rate as the economic outlook deteriorates. Second, as this unfavourable scenario unfolds there is a partial substitution of direct credit for intermediated credit: the supply of bank credit contracts while the volume of bonds outstanding expands, though not fully making up for the loss of bank credit because borrowing costs are higher. The model thus provides a convincing explanation in times of rising uncertainty or outright economic stress for the behaviour of the price of credit, measured in terms of a credit spread, and of credit quantities, measured in terms of the finance mix, which is the ratio of bank loans to the sum total of bank loans and the volume of bonds. ${ }^{5}$

The principal question this paper addresses is whether the signalling properties of credit spreads and finance mixes are useful for predicting future economic activity. If financial frictions are an important conduit through which shocks are transmitted from the financial sector to the real sector of the economy, then movements in credit spreads and finance mixes should contain useful and relevant information about the real economy in the near-term future. A natural question to ask is which of the two financial indicators - the price-based indicator or the quantity-based one - has better predictive ability? We answer this question by evaluating the predictive power of credit spreads and the finance mix variable for a number of economic indicators in ten member states of the euro area over the sample period 2003-2016 (March).

Three observations motivate this comparative study. First, over the past 20 years the financial landscape of Europe has changed markedly. Although banks remain the dominant source of credit for non-financial corporations in the euro area, their role as the almost exclusive provider of funding has been circumscribed. The bond or securities market has emerged as an attractive, viable credit alternative to bank loans, particularly since the start of the Global Financial Crisis. In 2008 bonds accounted for approximately 7 per cent of total non-financial corporation debt outstanding. By 2015 this share had increased to about 11 per cent. ${ }^{6}$ The growing importance of the bond market is reflected in both the growing number of bond issuers and the larger number of bond issues. ${ }^{7}$

\footnotetext{
${ }^{5}$ With the ACS model, the vexing identification problem does not arise as movements in the finance mix signal the transition of credit-constrained firms from the loan market to the bond market. As will be shown in the theoretical section, the catalyst for a reduction of bank lending is the perception of higher default risk on projects undertaken by firms but financed by banks.

${ }^{6}$ Banco de España (2015).

${ }^{7}$ Kaya and Meyer (2014) report that between 2008 and 2012 the number of bond issuers in the euro area more than doubled. More German firms relied on bond financing in the aftermath of the collapse of Lehman Brothers; in France, Italy, Spain, a similar phenomenon was observed later in the wake of the Sovereign Debt
} 
Despite the gradual trend observed towards greater reliance on bond financing in the euro area, the financial sectors of the individual countries are still fairly heterogeneous. Table 1 , compiled from the ECB's 2015 Report on Financial Structure, underscores that they vary considerably in both size and structure. Consider the rightmost columns. Measured as the ratio of assets held by the financial sector to GDP, in 2014 the Netherlands had the largest financial sector with a ratio of 13.2 and Greece had the smallest at 2.2. Germany's financial sector was about four times the size of GDP in 2014. In addition, there is considerable variation in the way the financial sector has evolved in each country since the crisis period began in 2008. For instance, between 2008 and 2014 there was a marked downward trend in the relative size of the financial sector in Austria, Germany and to a lesser extent Belgium, whereas the relative size of the financial sector trended upward in France and grew larger in Finland. Spain and Portugal saw the relative size of their financial sectors first increase and then decrease. Banks as monetary financial institutions account for at least 50 per cent of the overall size of the domestic financial sector in every country with the exception of the Netherlands. Across countries the share of bank assets has ranged between two and four times the level of GDP and has mirrored developments in the relative size of the domestic financial sector. $^{8}$ In light of such considerable variation in the significance and evolution of the financial sectors in the euro area, the purpose of the empirical investigation is in part to establish whether the structure and depth of financial sectors matter for the ability of financial indicator variables to predict economic activity.

Finally, previous studies such as $\mathrm{Ng}$ and Wright (2013) argue that the forecasting performance of financial indicators is both time-dependent and intimately linked to the root cause of economic downturns. Analysing US data, they find that the predictive ability of the credit spread improves markedly while that of the term spread disappears altogether in the latter part of the sample period 1985-2012. They conjecture that the improved forecasting performance of the credit spread may result from the substantial growth of the financial sector relative to the other sectors of the US economy during the 1990s up to the early 2000s. ${ }^{9}$ Reflecting further on why credit spreads have become better information variables, they state: "[But] our results are consistent with the idea that business cycle fluctuations have different origins. The recessions of the early 1980s were caused by the Fed tightening monetary policy so as to lower inflation, with the effect of both an inverted yield curve and two recessions. The origins of the Great Recession were instead excess leverage and a housing/credit bubble" (p. 1140). Thus structural imbalances within the financial sector of the economy may affect the information content of financial indicator variables. To what extent financial imbalances in Europe, which ultimately triggered shock waves first in financial markets and then in the real sectors of the European economy, had led to perceptible changes in country-specific credit spreads and finance mixes before and during the ruptures is another focal point of this paper.

Crisis. Adrian and Shin (2009) provide a glimpse of the growing importance of capital markets in the United States and the severe contraction of market-based credit during the Global Financial Crisis.

${ }^{8}$ There are stark differences between the EMU countries in the importance of the shadow banking sector (OFI). The shadow banking sector in the Netherlands is massive, equating to seven times the level of goods and services produced in 2012. It is twice as large as the traditional banking sector and expanding more rapidly. Belgium and Portugal, too, have sizeable shadow banking sectors whose size relative to GDP has however remained fairly constant since 2008. By comparison, the shadow banking sectors in Finland and Greece are very small. Pension funds account for a significant share of the financial sector only in the Netherlands. The insurance sector is most important in France, where its size equals approximately the level of nominal GDP.

${ }^{9}$ According to Greenwood and Scharfstein (2013), the share of the financial sector in total US GDP peaked at 8.3 per cent in 2006. This compares with 4.9 per cent in 1980. 
Table 1: Size and Structure of the Financial Sector in EMU Countries

\begin{tabular}{|c|c|c|c|c|c|c|c|c|c|c|c|c|c|c|c|}
\hline \multirow[b]{2}{*}{ Country } & \multicolumn{3}{|c|}{$\begin{array}{c}\text { Ratio of assets of MFI } \\
\text { to GDP }\end{array}$} & \multicolumn{3}{|c|}{ Ratio of OFI to GDP } & \multicolumn{3}{|c|}{ Ratio of PF to GDP } & \multicolumn{3}{|c|}{ Ratio of IC to GDP } & \multicolumn{3}{|c|}{ Ratio of FS to GDP } \\
\hline & 2008 & 2012 & 2014 & 2008 & 2012 & 2014 & 2008 & 2012 & 2014 & 2008 & 2012 & 2014 & 2008 & 2012 & 2014 \\
\hline Belgium & 3.6 & 2.8 & 2.7 & 1.8 & 2 & 1.8 & 0.03 & 0.04 & 0.05 & 0.6 & 0.7 & 0.8 & 6.0 & 5.6 & 5.3 \\
\hline Germany & 3.9 & 3.1 & 2.8 & 0.3 & 0.3 & 0.3 & 0.12 & 0.16 & 0.16 & 0.5 & 0.6 & 0.6 & 4.9 & 4.2 & 3.9 \\
\hline Greece & na & 2.1 & 2 & na & 0.1 & 0.1 & na & 0.002 & 0.002 & na & 0.1 & 0.1 & na & 2.3 & 2.2 \\
\hline Spain & 2.9 & 3.2 & 2.7 & 0.8 & 0.7 & 0.6 & 0.09 & 0.1 & 0.12 & 0.2 & 0.2 & 0.3 & 4.0 & 4.3 & 3.7 \\
\hline France & 3.7 & 3.8 & 3.8 & 0.4 & 0.4 & 0.4 & 0 & 0 & 0 & 0.8 & 1 & 1.1 & 4.9 & 5.2 & 5.3 \\
\hline Italy & na & 2.4 & 2.3 & na & 0.6 & 0.6 & na & 0.02 & 0.03 & na & 0.3 & 0.4 & na & 3.4 & 3.4 \\
\hline Netherlands & na & 3.4 & 3.3 & na & 7 & 7.3 & na & 1.5 & 1.8 & na & 0.7 & 0.7 & na & 12.6 & 13.2 \\
\hline Austria & 3.6 & 3 & 2.6 & 0.7 & 0.7 & 0.7 & 0.04 & 0.05 & 0.06 & 0.3 & 0.4 & 0.4 & 4.7 & 4.1 & 3.7 \\
\hline Portugal & 2.6 & 3.2 & 2.6 & 1.2 & 1.1 & 1 & 0.11 & 0.08 & 0.09 & 0.3 & 0.4 & 0.4 & 4.2 & 4.7 & 4.1 \\
\hline Finland & 2.1 & 3 & 2.8 & 0.1 & 0.1 & 0.2 & 0.02 & 0.02 & 0.02 & 0.2 & 0.3 & 0.3 & 2.4 & 3.4 & 3.3 \\
\hline
\end{tabular}

Note: Abbreviations: MFI = Monetary Financial Institutions, OFI = Other Financial Intermediary, PF = Pension Funds, IC = Insurance Company, FS = Financial Sector, GDP $=$ Gross Domestic Product, na $=$ not available .

The ratio of the size of the financial sector to GDP for a given year appears in the rightmost three columns and is calculated as the horizontal sum of the ratios of the four sub-sectors relative to GDP.

Slight discrepancies are due to rounding errors.

Source: Report on Financial Structure, ECB, October 2015 and author's own calculations. 
This study of aggregate credit conditions in ten EMU countries finds that movements in credit spreads are far more successful than movements in the external finance mix in predicting subsequent changes in real economic activity. This tends to support the theory-based contention by ACS (2013) that increasing risk premiums capture tightening credit market conditions better than a contraction of credit. However, the forecasting performance of the three credit spreads evaluated in this paper is uneven. The strongest evidence in favour of the predictive ability of credit spreads comes from the corporate bond market. A risk premium extracted from individual corporate bond yields predicts three measures of economic activity fairly well in Germany and Southern Europe. Two other credit spreads based on the cost of borrowing from banks, the 'spread' and the 'ECB-spread', have predictive power for some measures of economic activity but they fail to predict consistently across a range of either economic indicators or countries.

The remainder of the paper is organized as follows. Section 2 presents a highly selective review of the pertinent literature and explains the rationale behind using credit quantities and credit spreads as indicator variables. Section 3 discusses the theoretical underpinnings of the model of ACS (2013). The empirical findings are reported in Section 4. Section 5 concludes.

\section{Credit quantities vs. credit prices}

Credit spreads and finance mix variables as indicators of conditions in financial markets have their origin in the literature on the credit channel of monetary policy in the 1980s and early 1990s.

A quantity-based finance mix figures prominently in Kashyap, Stein, and Wilcox (1993) (KSW) who embed an expanded financial sector in a simple Keynesian model of aggregate demand to verify the existence of a bank lending channel in the transmission process of monetary policy. Larger firms can choose between bank loans and commercial paper to finance their investment spending. Bank loans are special, however, to a firm as bank credit signals the firm's creditworthiness to the wider public. In KSW's analysis financial markets function properly and there is only one genuine financial friction. ${ }^{10}$ Small bank-dependent firms cannot access the commercial paper market if the supply of bank loans contracts due to a tightening of monetary policy. The finance mix variable, defined as the ratio of bank loans to the sum of bank loans and commercial paper, has a straightforward signalling property. A decrease in the finance mix variable reflects more stringent financial conditions and should lead in due course to a reduction in aggregate demand. The empirical results reported in their paper support the view that changes in the finance mix had substantial predictive power for various measures of economic activity in the United States during the post-WW II period. KSW interpret these findings, which are based on highly aggregated data, as direct evidence for a bank lending channel in the US monetary transmission mechanism.

\footnotetext{
${ }^{10}$ DeFiore and Uhlig $(2011,2014)$ approach the issue of bank versus securities finance within a DSGE model characterized by agency cost. They argue that a switch from bank to bond finance occurs if the cost of acquiring information about projects rises suddenly for banks. To generate the change in the debt mix and sizeable increases in credit spreads simultaneously, two additional shocks, one affecting firms' uncertainty about their productivity, and the other affecting their probability of default are needed.
} 
Critical of this interpretation of the aggregate evidence, Oliner and Rudebusch (1996) point out that movements in the KSW finance mix variable may be due to compositional and behavioural changes on the part of firms rather than the existence of a bank lending channel. Subsequent empirical studies of the bank lending channel have therefore drawn on balance sheet data from individual banks to isolate shifts in banks' lending behaviour. Kashyap and Stein (2000) study the behaviour of all US commercial banks over 1976-1993 and find that small, less liquid banks cut their loan portfolios after monetary policy tightening. They view this finding as strong support for the existence of a bank lending channel but are coy about its quantitative importance. Using a unique data set of more than 2 million loan applications lodged in Spain over the period 2002-2008, Jimenez et al (2012) find considerable quantitative evidence in favour of a broad bank lending channel. Against a backdrop of tighter monetary or economic conditions, low capitalized and less liquid banks tended to cut their lending substantially. After identifying shifts in the supply of bank credit in micro-level data, Bassett et al. (2014) construct an aggregate credit supply indicator and estimate that shocks to the aggregate credit supply cause real output to decrease by 0.75 per cent after two years.

In a recent paper, Becker and Ivashina (2014) tackle the problem of identifying shifts in loan supply from the viewpoint of US non-financial corporations with access to both bank credit and the bond market. They observe a connection in micro-level data between changes in bank behaviour, seen as imposing tighter lending standards, suffering a greater share of non-performing loans, setting aside higher loan provisions, or the perceived performance of banks in their share price, and firms switching from bank debt to open-market debt. Realizing that small firms cannot issue bonds, Becker and Ivashina explore the ramifications of the behaviour of the larger, rated bond-issuing firms for smaller firms. They show that the ratio of bank loans to total external credit, computed for firms with access to both sources of credit, has predictive power for the likelihood of a small unrated firm getting a bank loan.

ACS (2013) examine both aggregate and firm-level data in an attempt to identify shifts in loan supply. They argue that the micro-economic evidence points overwhelmingly to shocks to credit supply by banks and other financial intermediaries as the key driver of changes in total aggregate credit outstanding. They further document a shift from bank debt to open market credit during the Great Recession. Analysing funding decisions reported by firms during the economic downturn of 2007-2009 in the US, they find a 75 per cent decrease in new bank loans while the volume of new bonds issued nearly doubled. In addition, they report a widening of credit spreads for both loans and bonds in micro-level data.

Credit spreads provide a timely signal of stress in financial markets. There are many factors that cause the difference to increase between, typically, a risky interest rate and a riskless (or less risky) interest rate: lenders sensing a higher probability of default by borrowers, a perception that the risk-bearing capacity of financial institutions and markets has decreased, assets becoming more illiquid as a result of turmoil in financial markets, a higher probability of a credit crunch, and others. ${ }^{11}$ By contrast, a substantial narrowing of a credit spread can

${ }^{11}$ Bernanke and Gertler (1989) is one of the early theoretical contributions that stresses the importance of financial factors such as a firm's cash flow in influencing the cost of external relative to internal finance. Borrowers' characteristics determine this interest spread which is central to the balance sheet view of the credit channel of the monetary transmission mechanism. In their set-up (or in later papers such as Bernanke, Gertler, and Gilchrist (1995)) there is only one homogenous financial sector that does not distinguish between banks and the bond market. 
indicate excessive risk-taking by financial market participants and reflect increasing vulnerability in the financial sector. Stein (2014) argues that watching credit spreads is essential for making good decisions on monetary policy. Curdia and Woodford (2011) provide theoretical support for this claim. In a sluggish economy a central bank can improve welfare by easing monetary policy to counter a rising credit spread.

Stock and Watson (1989), Friedman and Kuttner (1992) and Gertler and Lown (1999) are early attempts to measure the forecasting power of credit spreads for economic activity. More recent examples are Philippon (2009) who shows that a variant of Tobin's q, which varies proportionately with a credit spread based on US corporate and government bond yields, predicts capital investment much better than the standard Tobin's q based on equity prices. The excess bond premium extracted from the difference between yields on corporate and synthetic bonds is a powerful predictor of US economic activity according to Gilchrist and Zakrajšek (2012). Ng and Wright (2013) find that the increase in the forecasting power of the credit spread computed by Gilchrist and Zakrajšek for the US is due to higher leverage and the rising importance of financial factors in shaping the US business cycle. Krishnamurthy and Muir (2015) find that credit spreads combined with information about pre-crisis credit growth predict the severity of financial crises.

\section{A theoretical foundation}

The theoretical framework underlying our empirical analysis follows ACS (2013). They investigate the effect of changes in default risk on the credit market in both absolute and relative size. The credit market is fed on the supply side by two sources. Banks supply intermediated credit while households offer direct credit through the purchase of bonds from companies. The two suppliers of credit have different attitudes towards risk. While banks are risk-neutral, households are risk-averse. The recipients of bank credit and open-market credit invest the funds in projects that have a low probability of default and whose payoffs are determined by both aggregate and idiosyncratic factors. Changes in market perceptions set a chain of events in motion. They are mirrored in a change of the probability of default, which in turn affects the risk premium and hence borrowing rates. Changes in the risk premium also change the composition of credit supply through opposite shifts in bank credit and household credit with only a secondary effect on credit demand.

We next sketch out the essential elements of the model.

\section{Banks}

Banks accept deposits (liabilities) and make loans (assets). The ratio of notional liabilities to notional assets for a 'successful' bank is given by

$$
\frac{(1+f) L}{(1+r) C_{B}}=\psi(\varepsilon, \alpha, \rho)
$$

where $\quad r=$ lending rate

$f=$ interest rate on deposits (riskless rate)

$L=$ liabilities 
$C_{B}=$ bank credit (loans)

$\varepsilon=$ project risk (probability that a project will fail $\rightarrow$ default)

$\alpha=$ value at risk (probability that the bank will fail)

$\rho=$ weight on the aggregate factor in determining the project's pay-off.

For a successful bank the value of its notional assets exceeds the value of its notional liabilities. Hence $\psi(\varepsilon, \alpha, \rho)<1$.

Combining (1) with the balance sheet constraint $C_{B}=L+E$ yields the supply of bank credit:

$$
C_{B}=\frac{E}{1-\frac{1+r}{1+f} \psi}
$$

From now on assume that the risk-free rate on deposits equals zero: $f=0$.

\section{Households}

Households have mean-variance preferences. They solve the standard optimization problem that yields the optimal weight on the risky asset, which is bonds. The total supply of household credit (demand for bonds) is given by

$$
C_{H}=\frac{T((1-\varepsilon)(1+r)-1)}{\sigma^{2}(1+r)^{2}}
$$

where $\quad T=$ a measure of risk tolerance

$\sigma^{2}=$ variance of the realized value of bonds, which depends on $\varepsilon$ and $\rho$.

The risk premium is the expected return on the risky asset minus the return on the riskless asset:

$$
\pi=(1-\varepsilon)(1+r)-1
$$

Equation (3) has a simple interpretation: the supply of household credit varies proportionately with the risk premium on bonds adjusted for risk. ${ }^{12}$

\section{Market Clearing Condition}

Combining equations (2) and (3) yields the total supply of credit. The demand for credit $C^{D}$ depends inversely on the risk premium.

$$
C^{D}=K(\pi) \quad \text { with } K^{\prime}(\pi)<0
$$

Setting credit supply equal to credit demand yields

$$
C_{B}+C_{H}=K(\pi) \quad \text { or }
$$

${ }^{12} \mathrm{ACS}$ define $\sigma^{2}$ as the variance of one unit of notional assets so that $\sigma^{2}(1+r)^{2}=\operatorname{Var}\left(\frac{w(Y)}{C}\right)$. $\frac{w(Y)}{C}$ is the ratio of the realized value of the bond to its face value and $Y$ represents an economy-wide fundamental factor. 


$$
\frac{E}{1-\frac{1+\pi}{1-\epsilon} \psi}+\frac{T(1-\epsilon)^{2} \pi}{\sigma^{2}(1+\pi)^{2}}=K(\pi)
$$

where the definition of the risk premium (equation (4)) has been used to substitute for the interest rate.

\section{Tracing the Effects of a Change in Market Sentiment on Credit Conditions}

Using this highly stylized model, ACS then turn their attention to determining the effect of worsening economic conditions on the market price of risk and the willingness of banks and households to offer credit. They ask two specific questions:

Q1: How does the risk premium $\pi$ react to increases in the probability of project default (worsening economic fundamentals) $\varepsilon$ ?

Q2: What are the implications of worsening economic fundamentals for the size of the banking sector and the bond market?

To answer the first question, ACS define excess demand as

$$
\begin{aligned}
& G(\pi, \varepsilon)=C_{B}+C_{H}-K(\pi) . \\
& \text { It follows that } \quad \frac{\partial G}{\partial \pi} \frac{d \pi}{d \varepsilon}+\frac{\partial G}{\partial \varepsilon}=0 .
\end{aligned}
$$

Solving equation (9) for $\frac{d \pi}{d \varepsilon}$, they obtain:

or

$$
\frac{d \pi}{d \varepsilon}=-\frac{\frac{\partial G}{\partial \varepsilon}}{\frac{\partial G}{\partial \pi}}
$$

$$
\frac{d \pi}{d \varepsilon}=-\frac{\frac{\partial C_{B}}{\partial \varepsilon}+\frac{\partial C_{H}}{\partial \varepsilon}}{\frac{\partial C_{B}}{\partial \pi}+\frac{\partial C_{H}}{\partial \pi}-\frac{\partial K}{\partial \pi}}>0
$$

The derivative in expression (11) is strictly positive as the partial derivatives in the numerator are negative but positive in the denominator. ${ }^{13}$

Supplying an answer to the first question is thus straightforward: the risk premium increases as project risk increases. The 'required' return rises relative to the riskless rate and credit becomes more expensive.

To provide an answer to the second question, ACS construct iso-lending curves for banks and bond investors. ${ }^{14}$ The iso-lending curve is steeper for banks than for bond investors

\footnotetext{
${ }^{13}$ For this result to hold unambiguously $\varepsilon$ must be small and $\pi<1$, meaning the risk premium is small.

${ }^{14}$ An iso-lending curve shows the relationship between $\varepsilon$ and $\pi$ for a fixed amount of credit provided by a credit supplier
} 
because banks are risk-neutral while households are risk-averse. Suppose initially banks and bond investors supply the same amount of credit and the credit market is in equilibrium. Then market fundamentals deteriorate, driving up $\varepsilon$. The sequence of events unfolding is captured in Figure 1. The increase in $\varepsilon$ causes bank lending to contract, leading to a rightward shift of the iso-lending curve of the banking sector. The risk premium $\pi$ rises. For the credit market to clear, the bond market must make up the shortfall of credit supply relative to demand, which shrinks as $\pi$ rises. The rise in $\pi$ induces households to close the existing gap between demand and supply by providing more bond financing, resulting in an upward shift of the iso-lending curve of households. A new equilibrium is reached where the overall supply of credit has fallen.

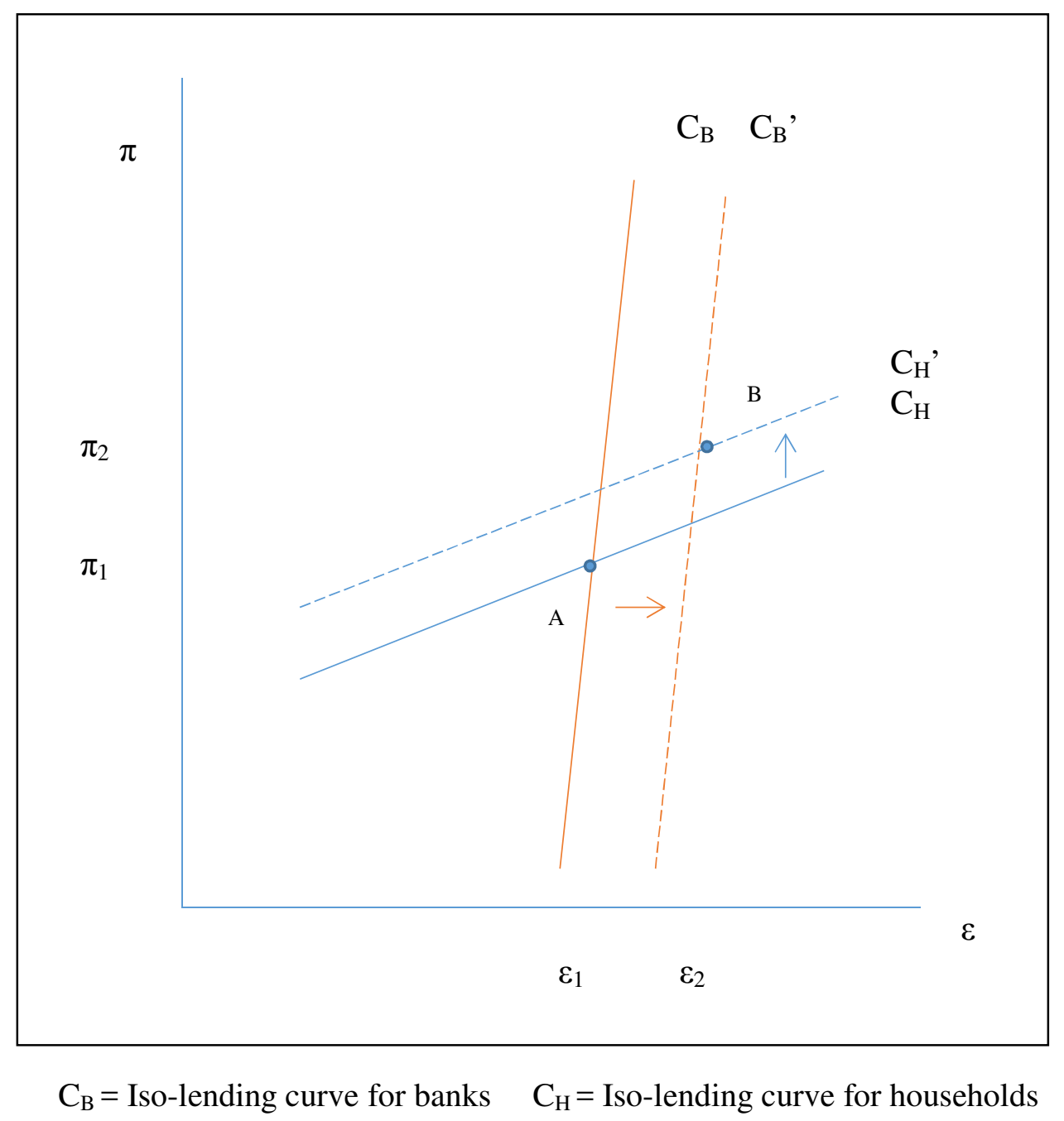

Figure 1: The change in the relative size of the banking sector and the securities market

The model thus provides a ready answer to the second question. In the wake of an increase in default risk, the absolute size of the banking sector shrinks while the bond market expands. The relative size of the banking sector shrinks. 


\section{Macroeconomic Implications}

The model just described gives rise to two clear-cut predictions about the behaviour of credit quantities and credit prices as the state of the economy - proxied by default risk - deteriorates. First, there are opposite movements in the components of credit: the volume of bank loans decreases while the volume of bonds increases. Second, the increase in the risk premium raises borrowing costs as the spread between the cost of borrowing and the riskless interest rate increases.

The predicted behaviour of credit quantities and prices in a changing economic environment is verified empirically in the next section. The intent is to establish whether movements in the quantity or prices of credit are better at predicting future economic activity in EMU countries.

\section{The empirical analysis}

In this section we examine developments in credit and output/labour markets in ten member countries of the euro area over the period 2003-2016 (March) from an empirical perspective. The countries included in the study are: Austria, Belgium, Finland, France, Germany, Greece, Italy, the Netherlands, Portugal, and Spain. ${ }^{15}$ The data frequency is monthly observations of credit quantities, credit prices, and economic activity. Table 2 gives an overview of the scope of the empirical analysis and the data used in it.

Our assessment of conditions in credit markets begins with an in-depth analysis of the quantity of credit outstanding - bank loans to non-financial corporations and securities issued by them - in the EMU countries before, during, and after the onset of financial crises. ${ }^{16}$ This is followed by an examination of borrowing costs and interest rate spreads that captures the sentiment towards risk in credit markets during periods of turbulence and relative calm.

\footnotetext{
${ }^{15}$ Other EMU countries could not be considered because of a lack of data.

${ }^{16}$ Other components such as loans from insurance companies or trade credit are excluded.
} 
Table 2: Scope of the Study and Data Employed in the Empirical Analysis

\begin{tabular}{|l|l|}
\hline Scope & $\begin{array}{l}10 \text { member countries of the euro area (Austria, Belgium, Finland, France, Germany, } \\
\text { Greece, Italy, the Netherlands, Portugal and Spain) }\end{array}$ \\
\hline Sample period & 2003-2016 (March) \\
\hline Data frequency & Monthly \\
\hline Measures of credit & $\begin{array}{l}\text { NFC=Total Bank Loans to Euro-Area Non-Financial Corporations reported by MFI } \\
\text { Institutions Excluding the ESCB } \\
\text { NFCSEC=Volume of Securities Issued by Non-Financial Corporations (Securities } \\
\text { Other Than Shares; All Currencies Combined). }\end{array}$ \\
\hline Credit spreads & $\begin{array}{l}\text { Spread = Cost of Borrowing for Non-Financial Corporations - 3 mo Money Market } \\
\text { Rate (calculated by the author). } \\
\text { ECB-Spread = CoBNFC (across maturity spectrum) - Swap Rate (calculated and } \\
\text { published by the ECB). }\end{array}$ \\
$\begin{array}{l}\text { Official Definition of the ECB-Spread: Lending spread; weighted spread between the } \\
\text { (MIR) rate for NEW NFC loans and the swap rate with maturity corresponding to the } \\
\text { loan category initial period of rate fixation. } \\
\text { GZ-Spread = Yield on Corporate Bonds - Yield on Synthetic (risk-free) Bonds } \\
\text { averaged over all corporate bonds. }\end{array}$ \\
\hline $\begin{array}{l}\text { Measures of } \\
\text { economic activity } \\
\text { Turnover of Capital Goods }\end{array}$ \\
\hline Data sources & Statistical Warehouse of ECB, EUROSTAT, DATASTREAM \\
\hline
\end{tabular}

\subsection{Credit quantities}

Figure 2 conveys the relative importance for non-financial corporations on the European continent of the two separate sources of credit, bank loans and corporate securities. ${ }^{19,20}$ It is readily apparent that no single uniform finance pattern applies to the ten EMU countries. Instead, the countries fall into three broad categories characterized by the share of securities relative to total credit outstanding. The first category comprises countries where bank loans are by far the most important source of credit, where securities account for less than 15 per cent of the sum total of bank loans and securities. ${ }^{21}$ The countries that fall into this category are Germany, Greece, Italy and Spain. The second category consists of Austria, Belgium, the Netherlands and Portugal, countries where securities represent between 15 and 30 per cent of the sum total of credit outstanding. In the two remaining countries - Finland and France firm-issued securities are a significant alternative source of credit, accounting for at least 30 per cent of credit.

\footnotetext{
${ }^{17} \mathrm{ESCB}=$ European System of Central Banks

${ }^{18} \mathrm{CoBNFC}=$ Cost of Borrowing for Non-Financial Corporations; MIR = Monetary and Financial Institution (MFI) Interest Rate

${ }^{19}$ Following Adrian, Colla, and Shin (2013), we do not consider a third important source of finance, the issuance of additional stock by companies.

${ }^{20}$ The two shaded areas represent European-wide recessions as determined by the Euro Area Business Cycle Committee of CEPR. The first recession started in the second quarter of 2008 and lasted until the end of the second quarter of 2009. The second recession lasted from the fourth quarter of 2011 until the first quarter of 2013.

${ }^{21}$ This assessment is based on the average of the ratio of securities to the sum of securities and bank loans over the sample period.
} 

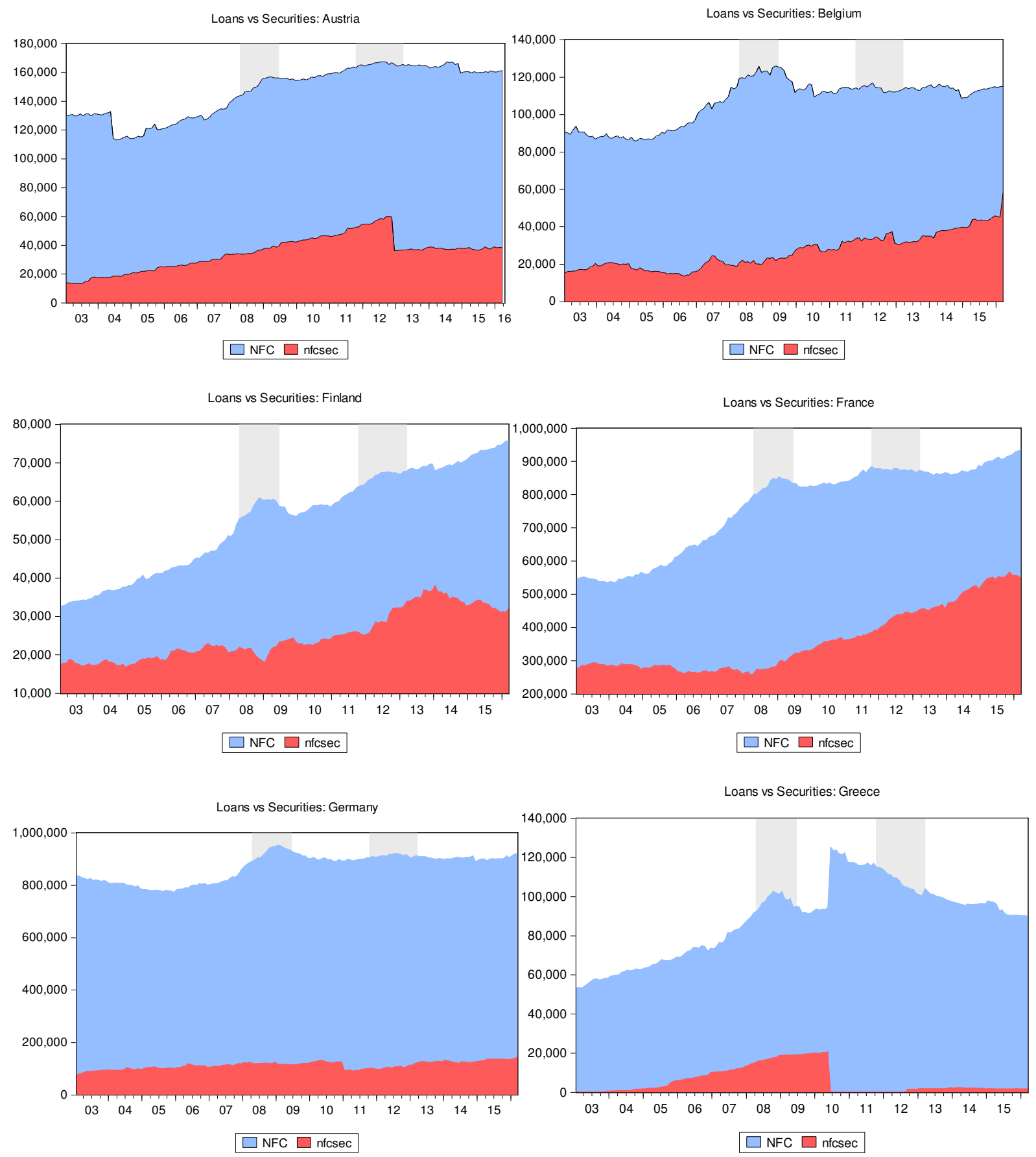

Figure 2: The relative importance of bank loans and securities (million euros)

Note: $\mathrm{NFC}=$ Bank Loans to Non-Financial Corporations NFCSEC $=$ Securities Issued by Non-Financial Corporations. Shaded areas are recessions in Europe as determined by CEPR. 

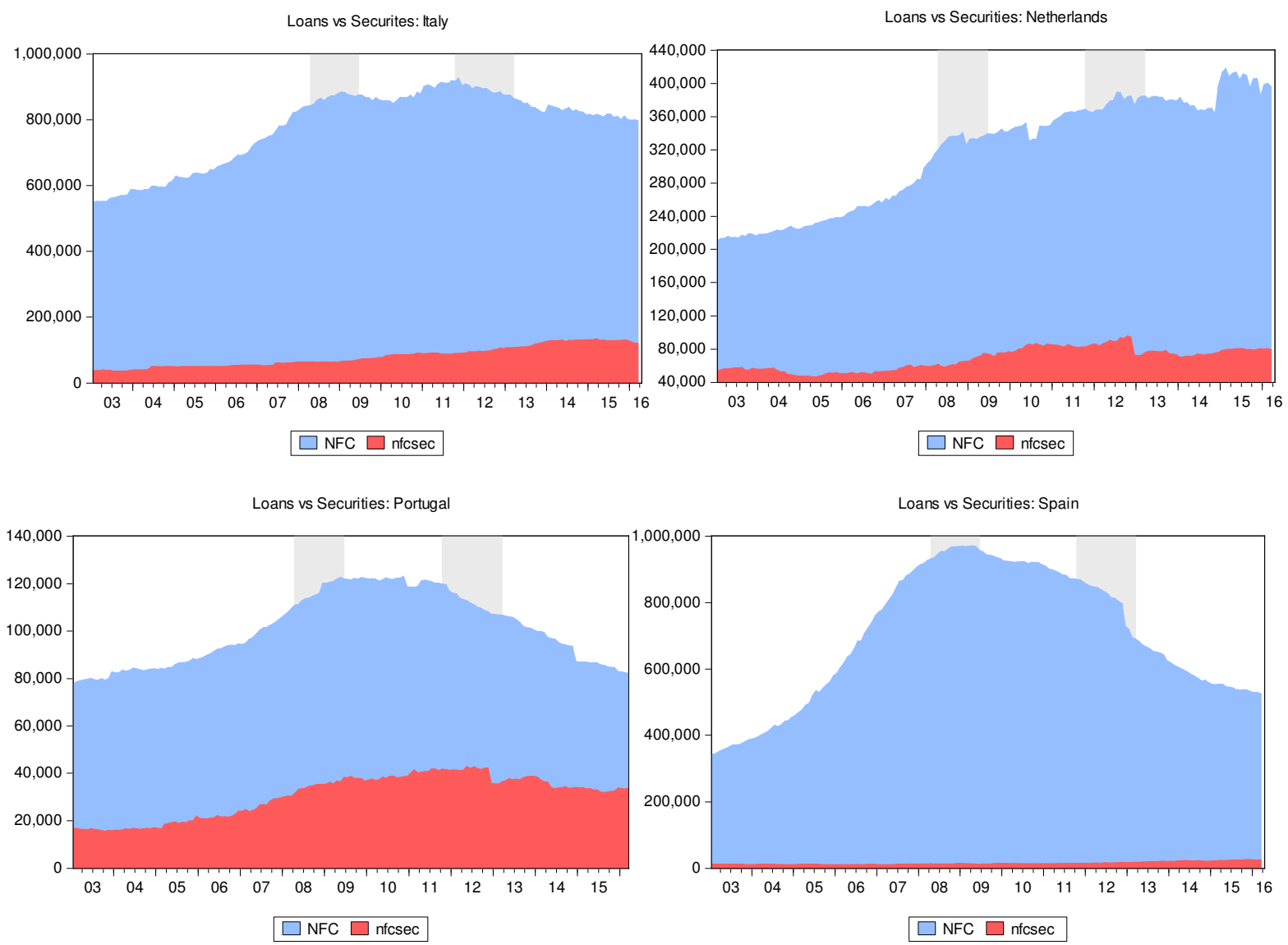

Figure 2: The Relative Importance of Bank Loans and Securities (million euros)(cont.)

Note: NFC = Bank Loans to Non-Financial Corporations; NFCSEC = Securities Issued by Non-Financial Corporations. Shaded areas are recessions in Europe as determined by CEPR.

Studying the graphs reveals further that in Belgium, France, and Portugal, the relative stature of the securities market has grown over time. In these countries the securities market has gained a larger share of the credit market at the expense of banking sector. In Austria, Filand, Germany, Italy, and the Netherlands, the relative share of securities issued has remained relatively constant while in Greece an expanding securities market provided temporary relief from cutbacks in bank loan supply before shutting down during the European Debt Crisis. The Greek securities market has only recently sprung back to life.

The next set of figures and the accompanying tables direct attention to the volume of real credit outstanding in each country, or the sum total of bank loans and securities deflated by the CPI. For each country we track the level of real credit (Figure 3A) and the changes in its components (Figure 3B) over the sample period. 

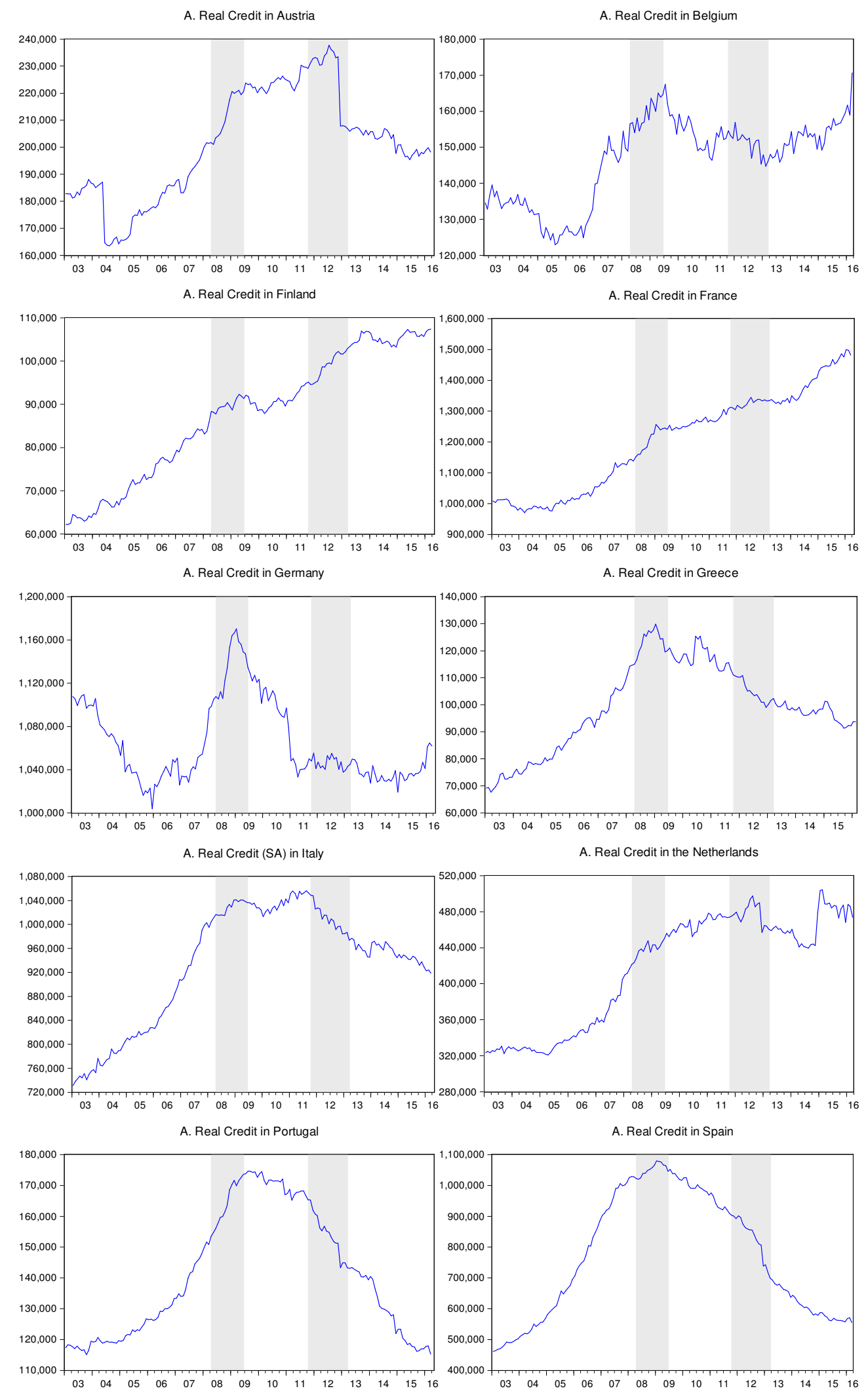

\section{Figure 3A: Real credit volume (million euros)}

Note: Real credit is defined as $\frac{\mathrm{NFC}+\mathrm{NFCSEC}}{\mathrm{CPI}} * 100$ where CPI $=100$ in 2015. 
B. Changes in Real Loans and Securities in Austria

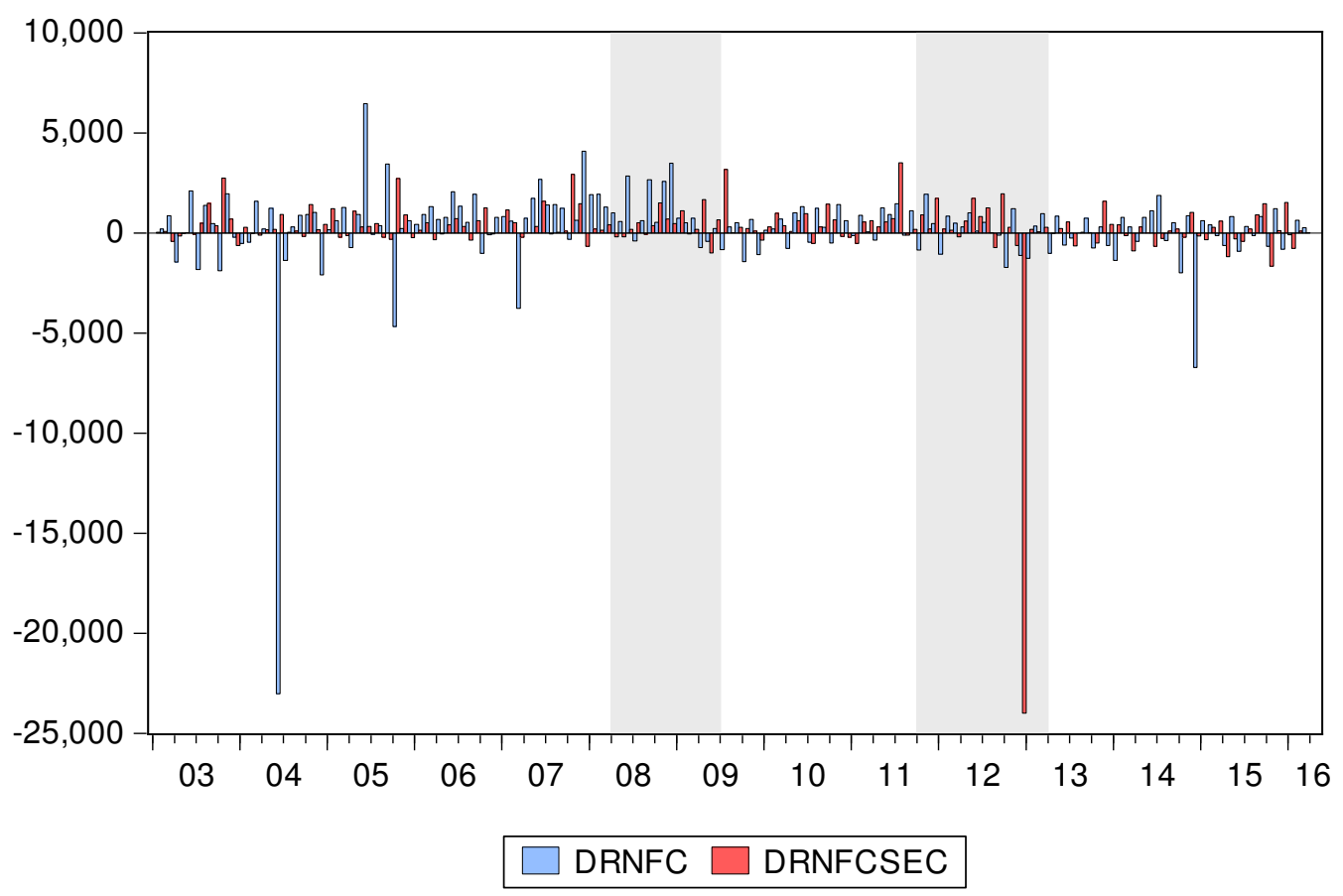

B. Changes in Loans and Securities in Belgium

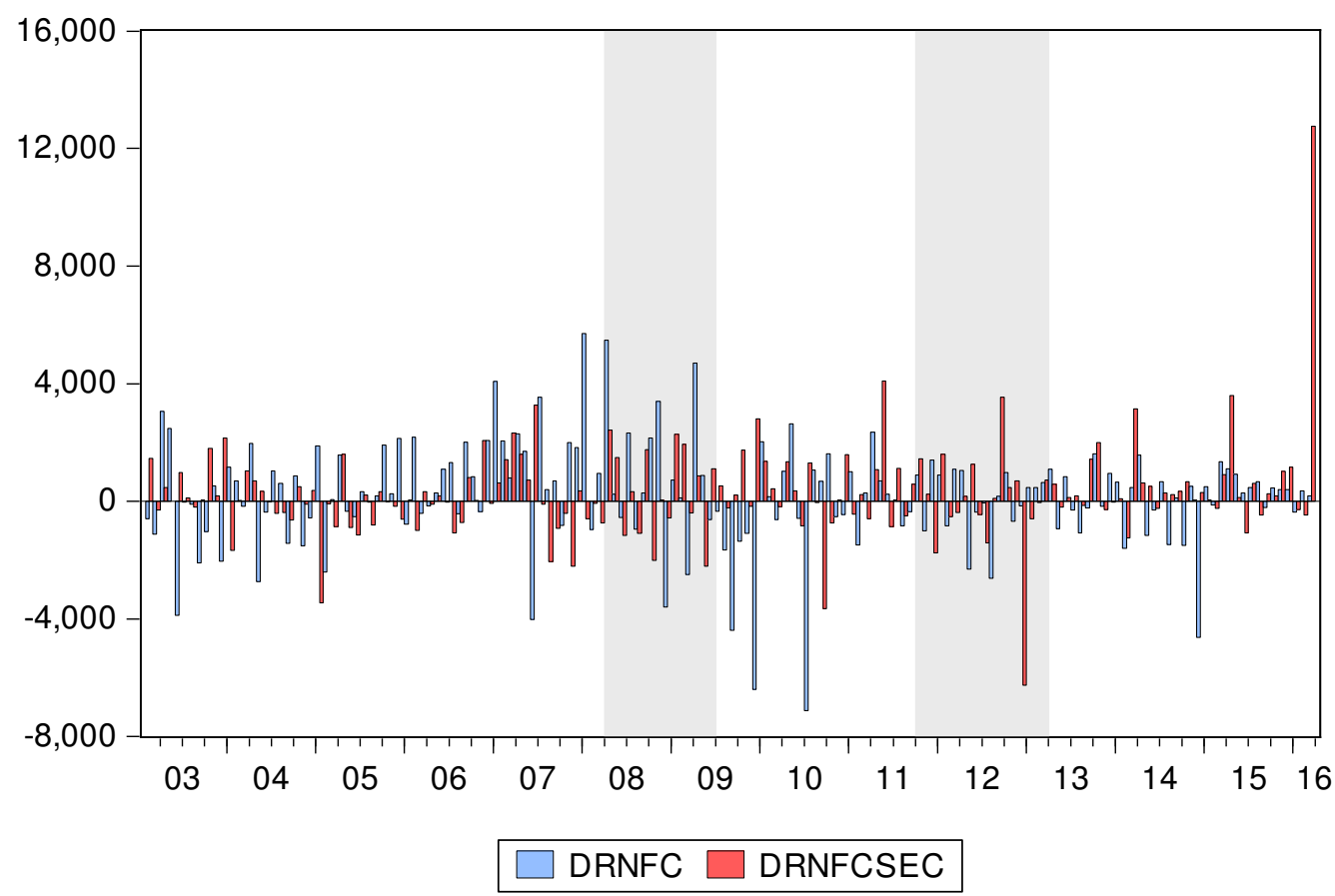

Figure 3B: Changes in loans and securities (million euros)

Note: DRNFC $=$ Change in real bank loans outstanding; DRNFCSEC $=$ Change in real securities outstanding (million euros). 
B. Changes in Real Loans and Securities in Finland

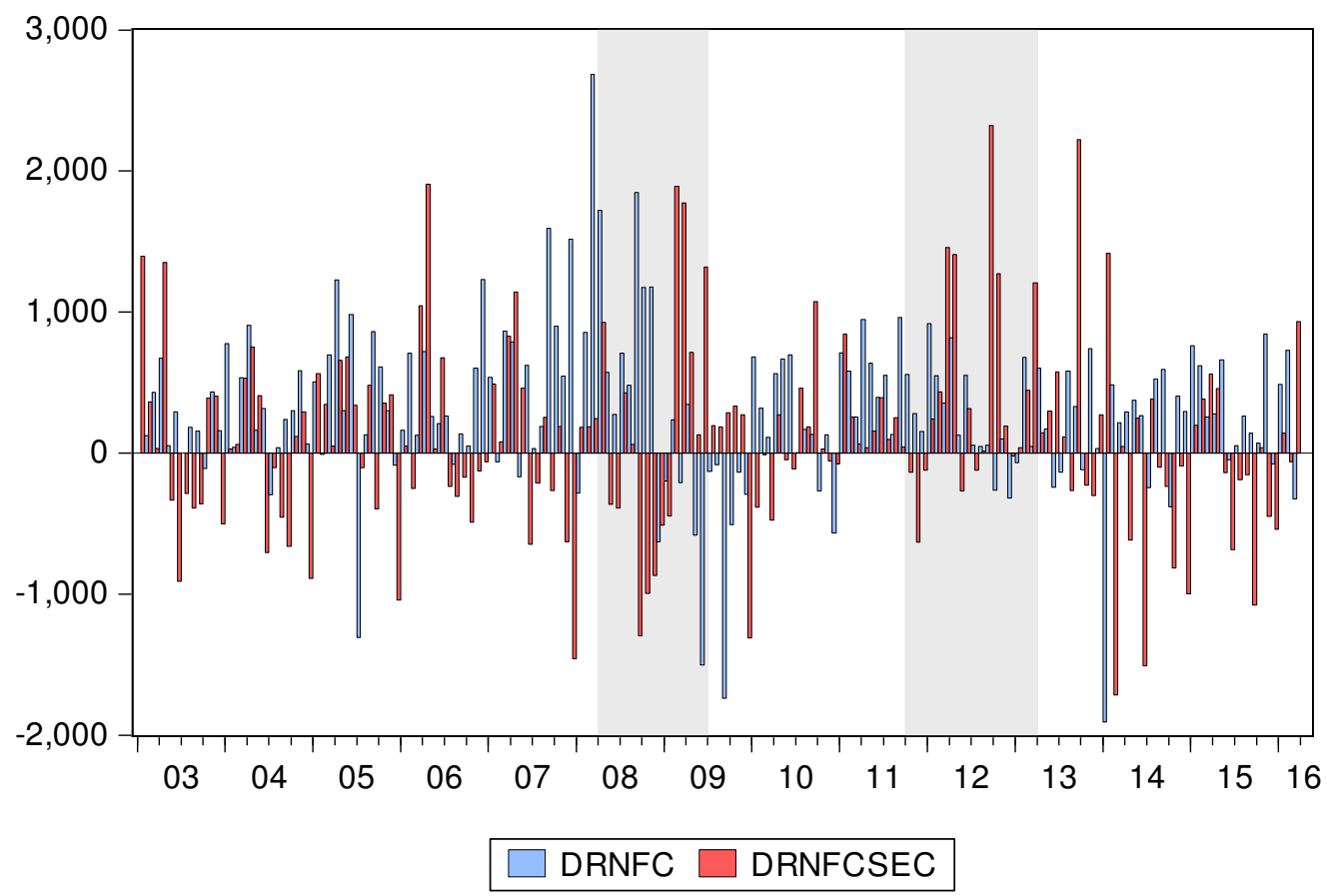

B. Change in Real Loans and Securities in France

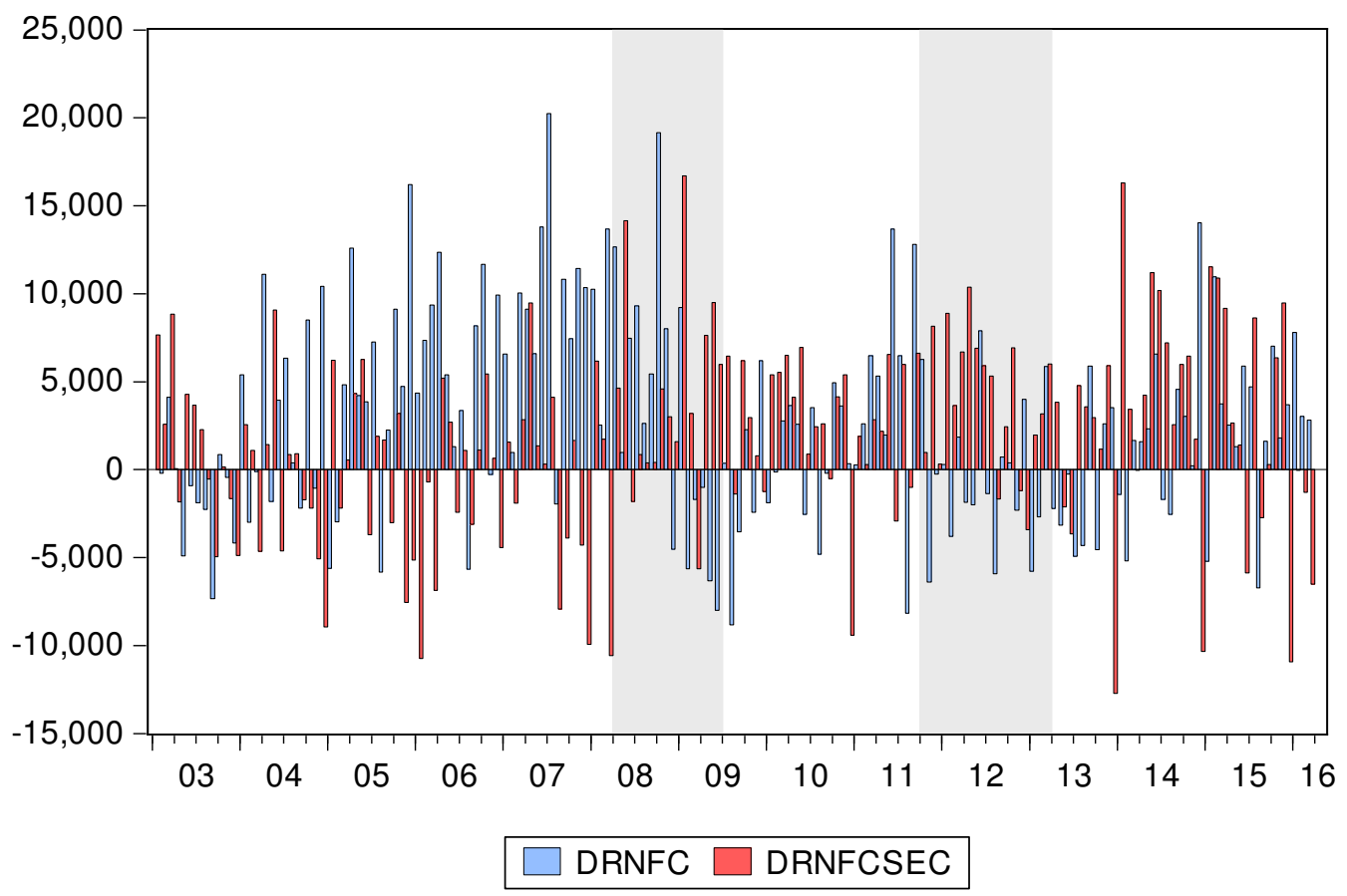

Figure 3B: Changes in loans and securities (million euros)(cont.)

Note: DRNFC $=$ Change in real bank loans outstanding; DRNFCSEC $=$ Change in real securities outstanding (million euros). 
B. Change in Real Loans and Securities in Germany

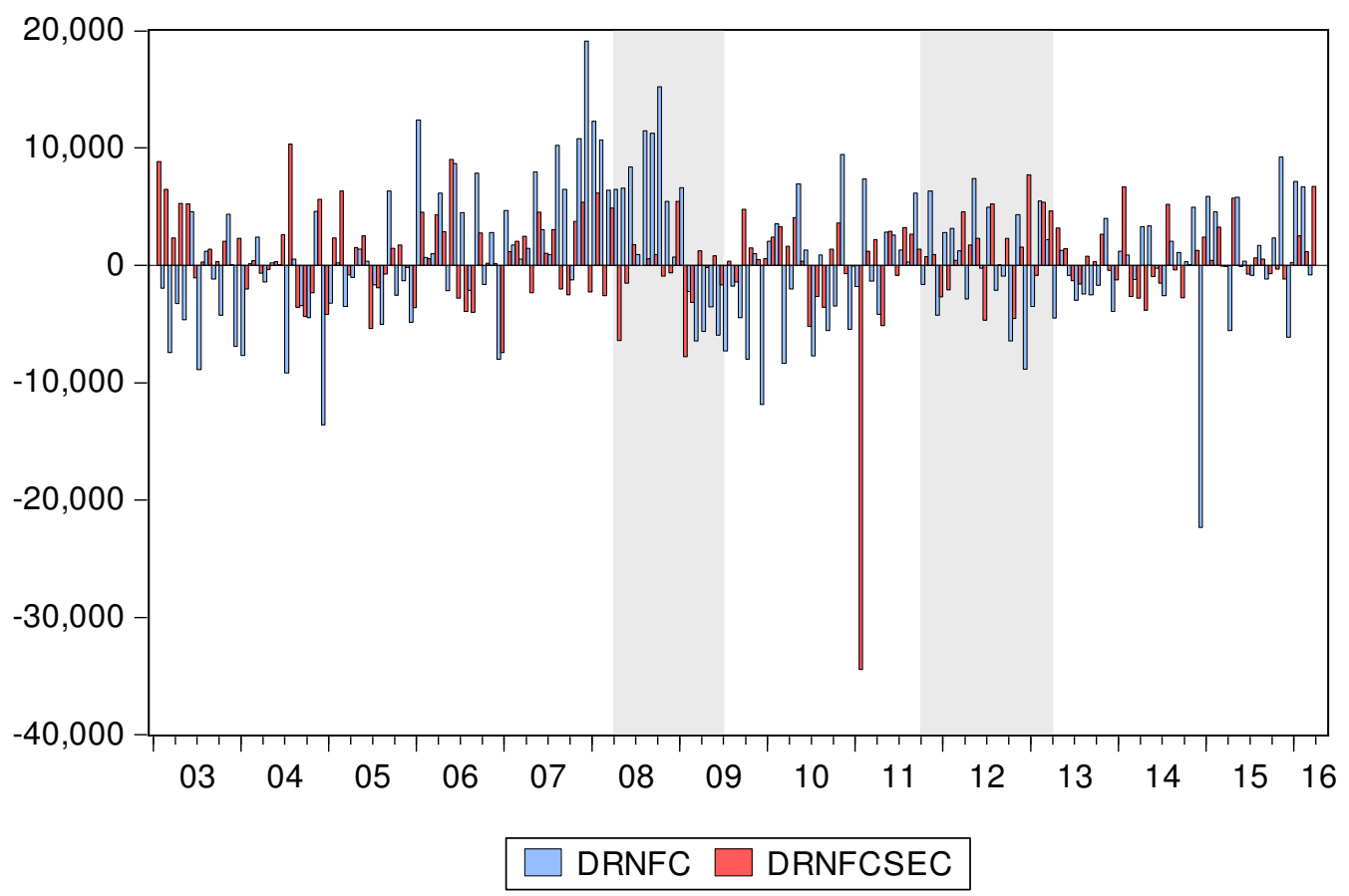

B. Change in Real Loans and Securities in Greece

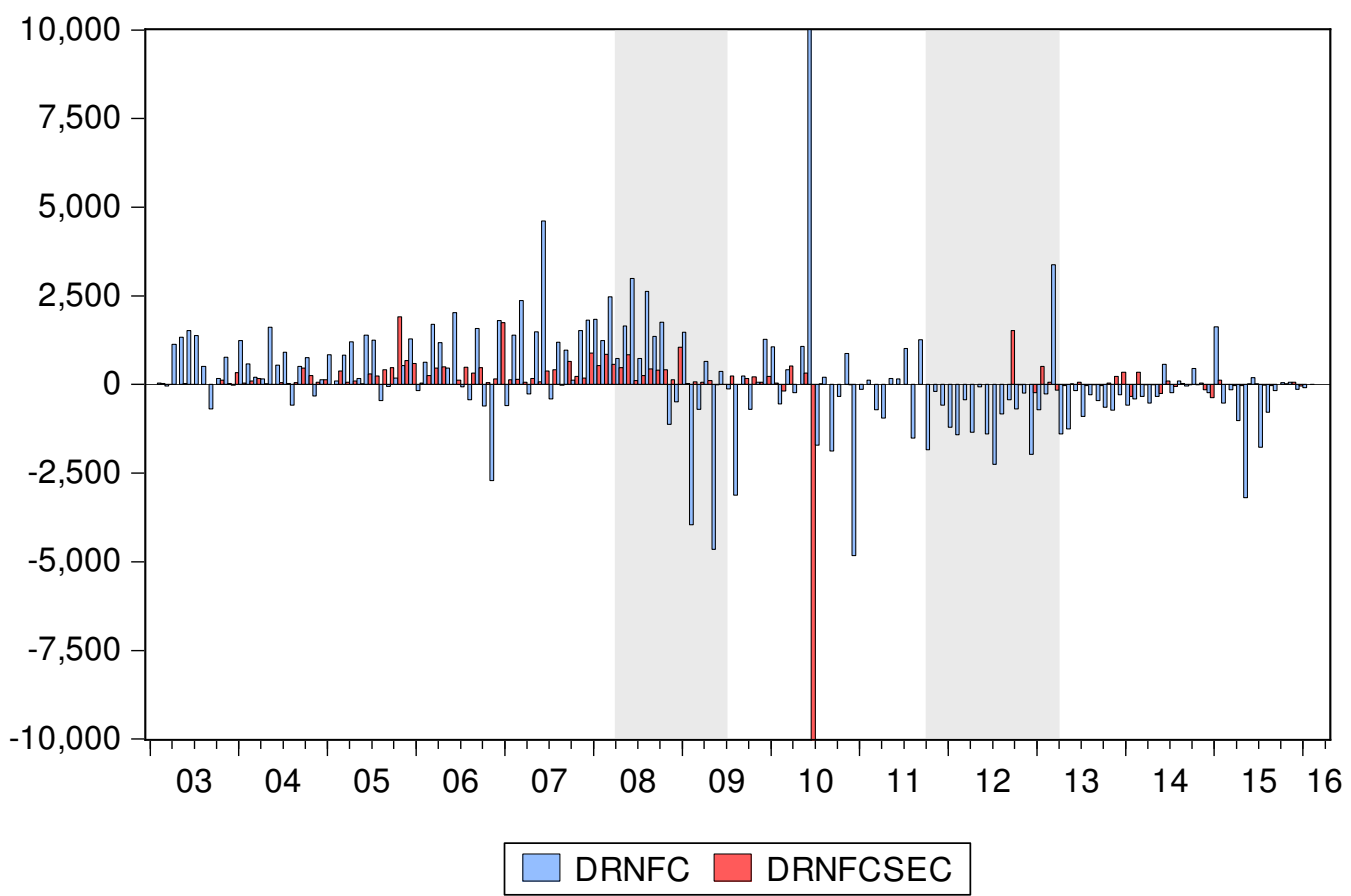

Figure 3B: Changes in loans and securities (million euros)(cont.)

Note: DRNFC $=$ Change in real bank loans outstanding; DRNFCSEC $=$ Change in real securities outstanding (million euros). 
B. Change in Real Loans and Securities in Italy

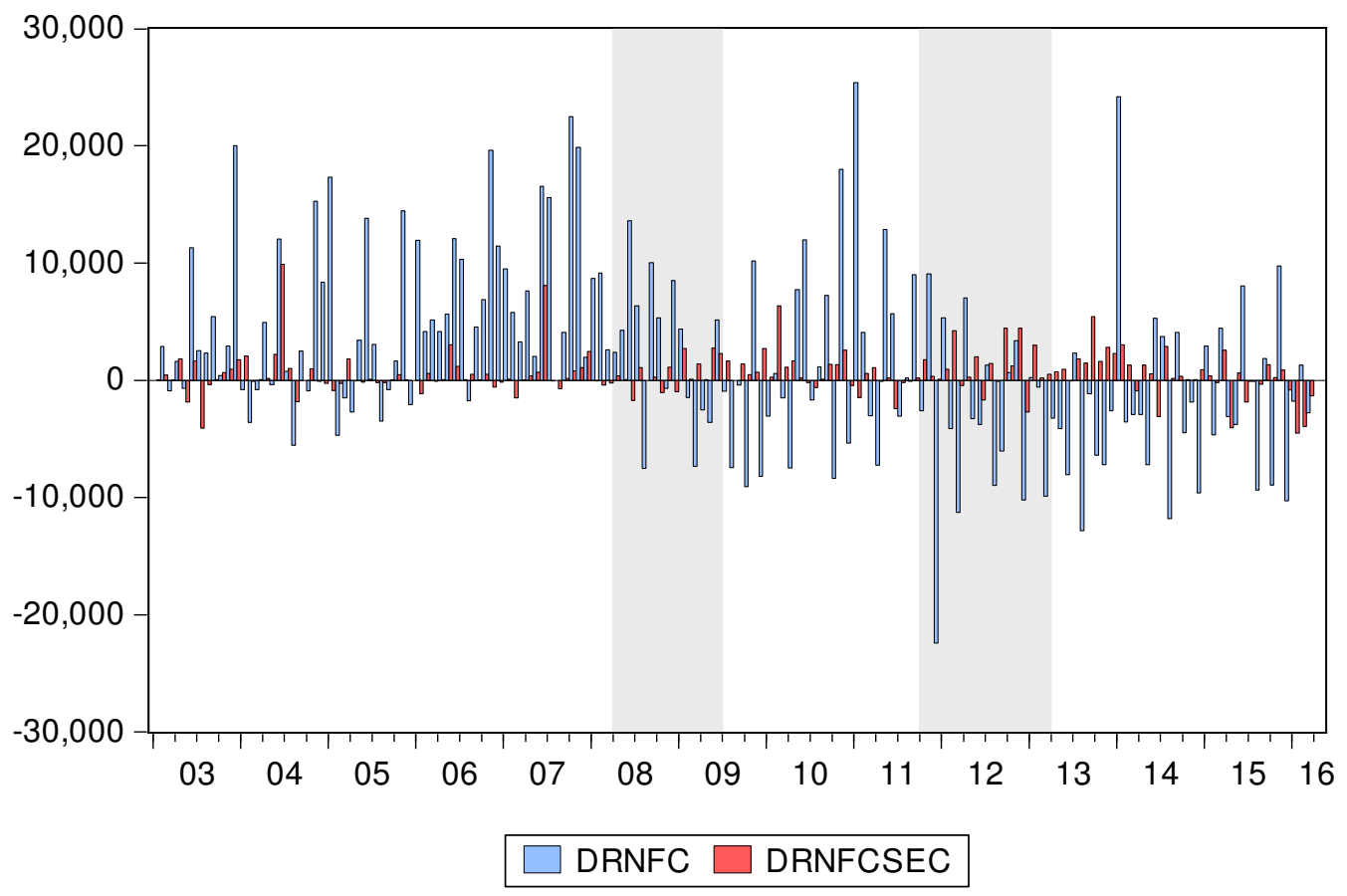

B. Change in Real Loans and Securities in the Netherlands

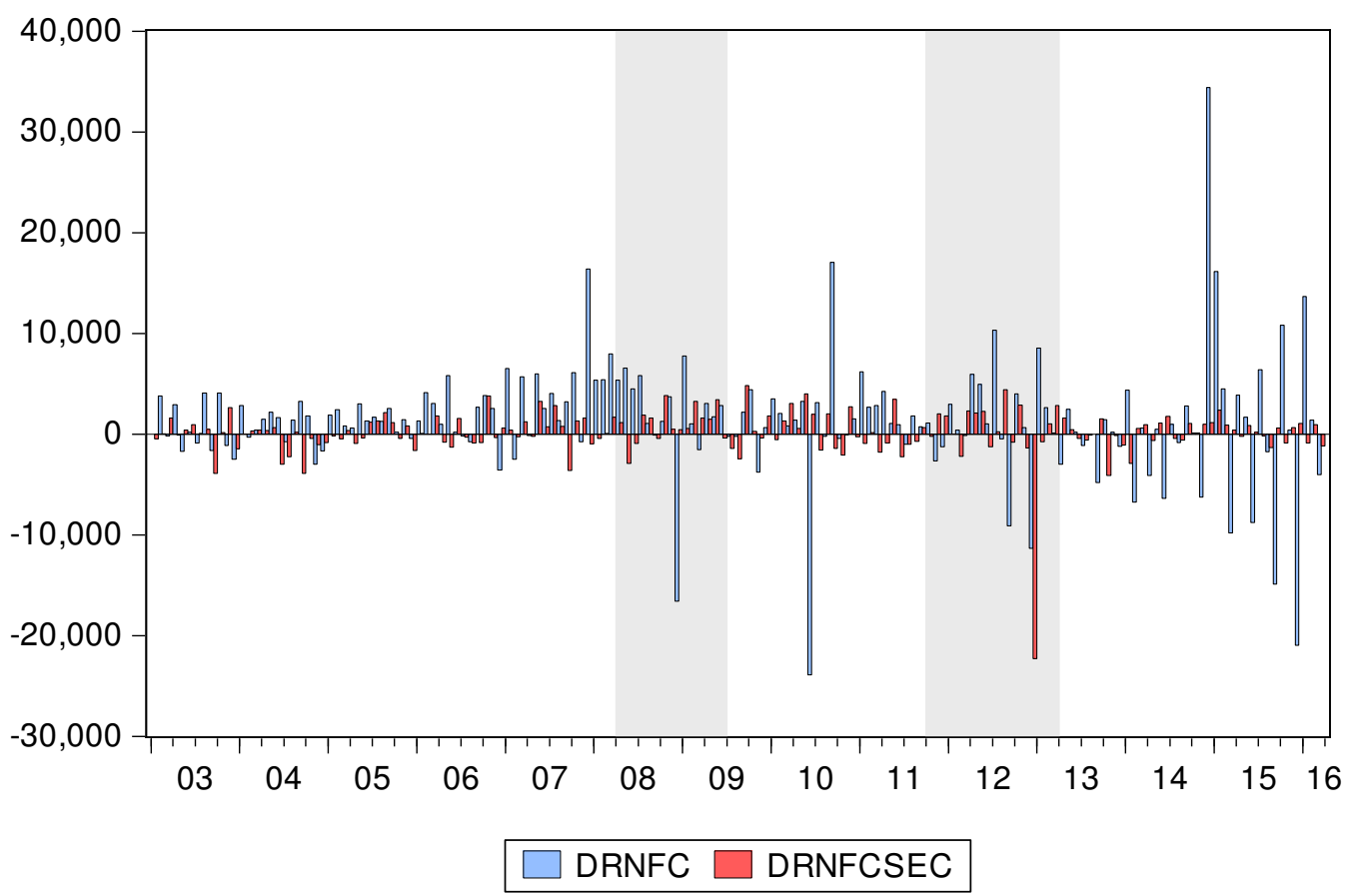

Figure 3B: Changes in loans and securities (million euros)(cont.)

Note: DRNFC $=$ Change in real bank loans outstanding; DRNFCSEC $=$ Change in real securities outstanding (million euros). 
B. Change in Real Loans and Securities in Portugal

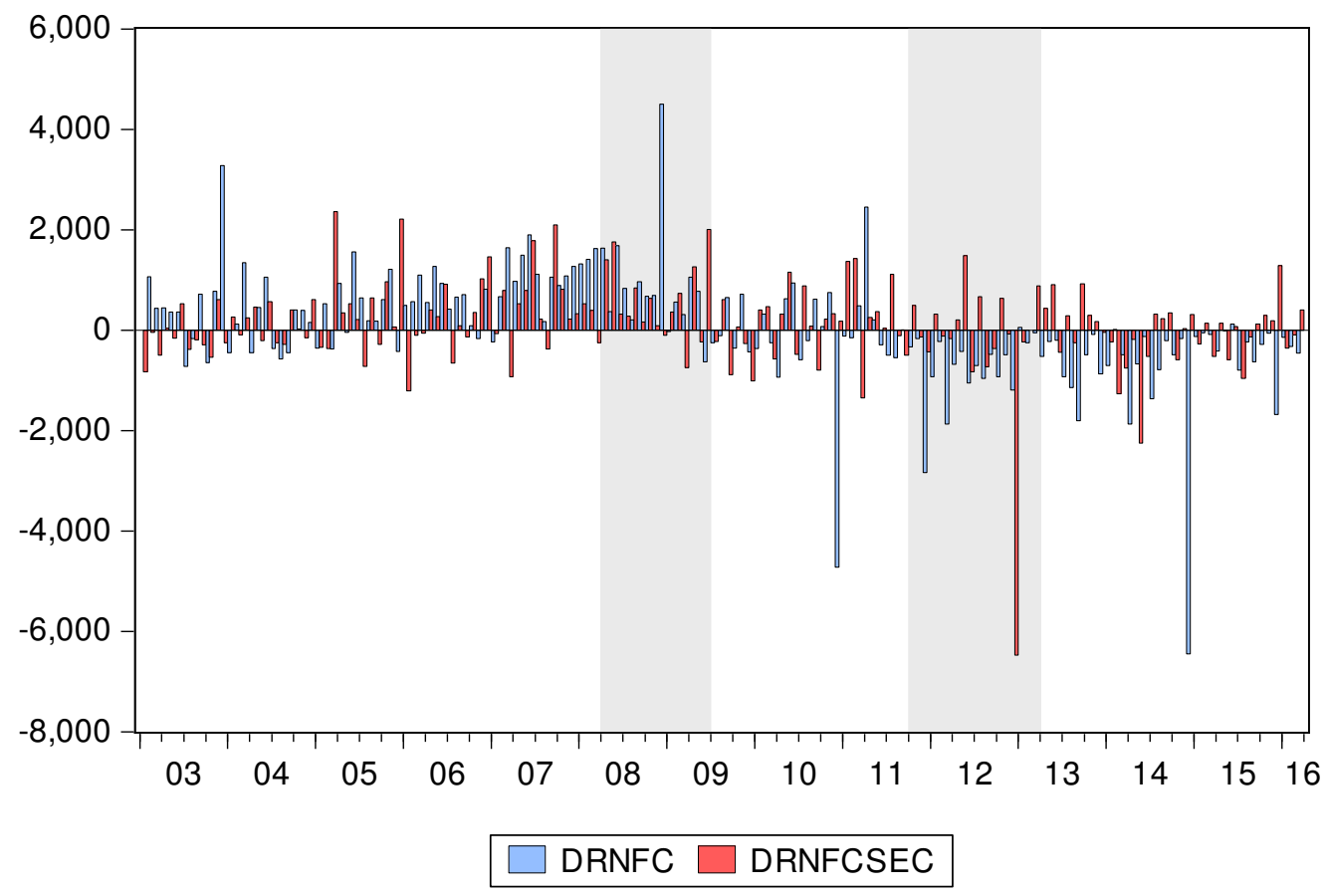

B. Change in Real Loans and Securities in Spain

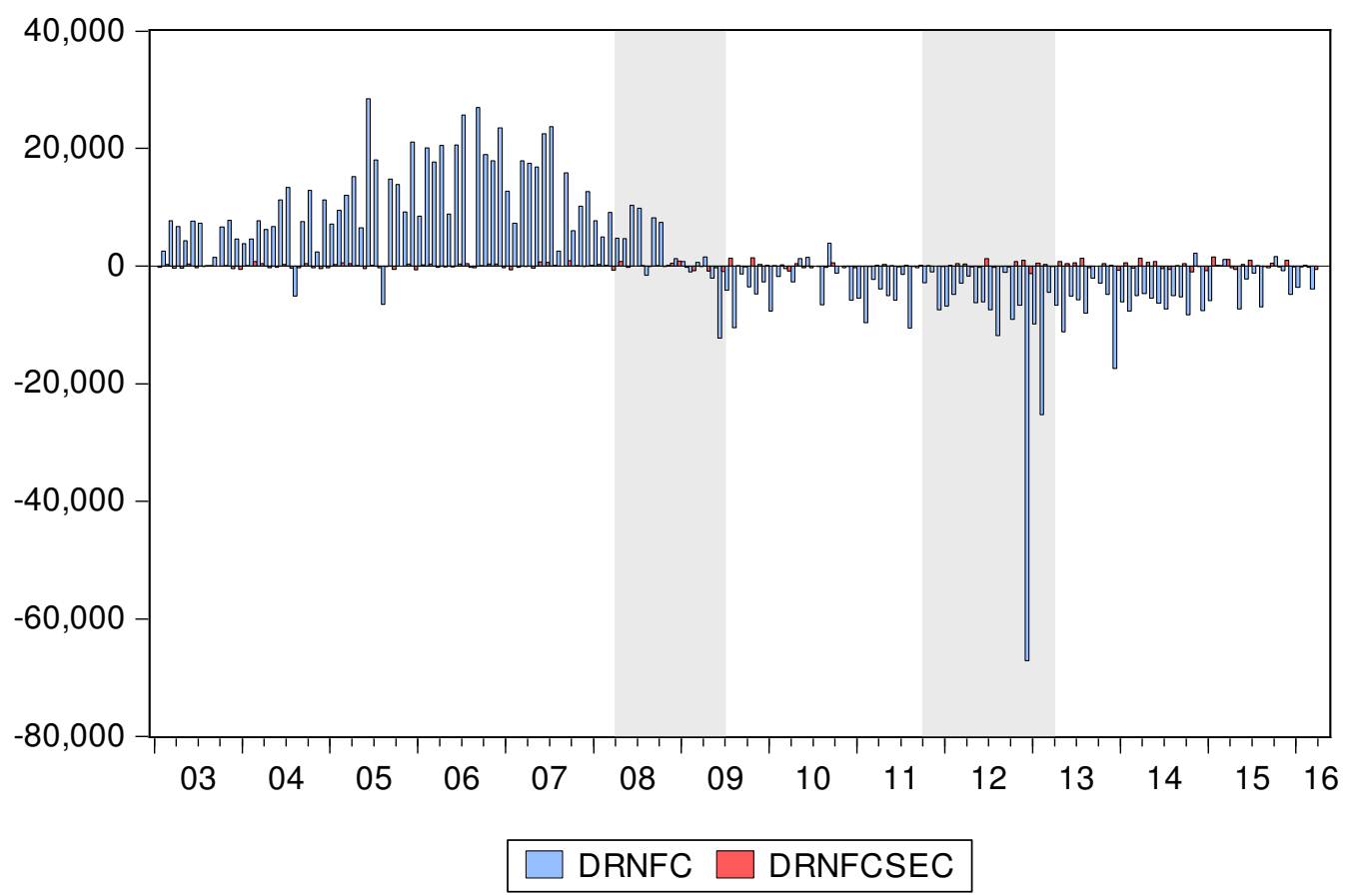

Figure 3B: Changes in loans and securities (million euros)(cont.)

Note: DRNFC $=$ Change in real bank loans outstanding; DRNFCSEC $=$ Change in real securities outstanding (million euros). 
Figure $3 \mathrm{~A}$ shows that the behaviour of real credit also defies a common pattern at the country level over time. In Finland and France real credit surged with minor exceptions throughout the sample period while other countries experienced more of a see-saw pattern. There are pronounced differences in the peaks but not in the troughs of real credit outstanding in the individual countries. In Germany, Greece, Portugal, and Spain, real credit attained its maximum either during or on the heels of the recession triggered by the Global Financial Crisis in 2009. In Austria and Italy, the maximum occurred during or right before the onset of the second recession in 2011/12. ${ }^{22,23}$ Three countries - Belgium, Finland, and France - saw real credit peak in $2016 .{ }^{24}$ Table 3 provides summary information about the volume, growth rate and volatility of real credit. The level of real credit increased over the sample period in every country except Germany and Portugal. Finland recorded the highest average growth rate of real credit at 4.21 per cent and Germany the lowest at -0.28 per cent. By any measure, the volatility of the growth rate of real credit was severe. Only two countries - France and Germany - remained under the 10 per cent mark. Belgium at 23.68 per cent and Greece at 21.86 per cent recorded the highest standard deviation of the growth rate of real credit.

Inspection of Figure 3A yields a further noteworthy observation concerning the volume of real credit outstanding during recessions. It rose during the first recession in all countries but fell markedly during the second recession in all the countries on the southern flank and Austria, decreased moderately in Belgium and the Netherlands and remained virtually the same in Germany. ${ }^{25}$ Real credit continued to increase in Finland and France during the second recession.

Figure 3B shows the changes in the components of real credit outstanding over the sample period. This figure accentuates the shrinking of the volume of price-adjusted bank loans during the latter half of the sample period in the countries on the southern flank of the EMU, notably Portugal, Spain and to a lesser extent Greece and Italy. Table 4 provides further details about changes in the components of real credit during the two recessions of the sample period. Examining the cumulative change in the volume of real loans and securities outstanding during recessions should be helpful in assessing whether quantitative developments in credit markets support the bank lending view (ACS (2013), KSW (1993)), in which bank loans and securities are substitute sources of credit.

\footnotetext{
${ }^{22}$ The sudden drop in real loans outstanding in Austria in June 2004 is due to a break in the time series data caused by a decision to reclassify borrowers. For instance, loans taken out by freelance professionals and selfemployed people were shifted from 'loans to non-financial corporations' to 'loans to households'. The same applied for non-profit organizations. The negative spike in December 2012 is due to the redemption of securities which were not replaced with new issues due to low corporate investment activity at the time, as reported in the Financial Stability Report no 26, 2013 by the Austrian National Bank.

${ }^{23}$ In the Netherlands, real credit came close to peaking during the second recession in August 2012. At $€ 497539$ million it came close to the maximum of $€ 504493$ million recorded in February of 2015.

${ }^{24}$ It may seem surprising that real credit outstanding in France is higher than that in Germany. French firms rely on external sources of credit far more than their German counterparts, which draw more heavily on internal funds. For more information on this, see Deutsche Bundesbank (2014).

${ }^{25}$ Essentially this observation rests on comparing $\triangle\left(\frac{N F C L+N F C S E C}{P}\right)$ at the beginning and end of the recessions whereas the changes in Table 4 are based on the change in loans (securities) deflated by the CPI in each period and summed over the length of the recession $\left(\frac{\triangle N F C L}{P}, \frac{\triangle N F C S E C}{P}\right)$. The two concepts are related by the following formula: $\triangle R C=\frac{\Delta C}{P}\left(1-\frac{\pi}{g_{C}}\right)$, where $\triangle R C=\Delta\left(\frac{N F C L+N F C S E C}{P}\right), \frac{\Delta C}{P}=\frac{\Delta N F C L}{P}+\frac{\Delta N F C S E C}{P}, \pi=\frac{\Delta P}{P}$ and $g_{C}=\frac{\Delta C}{C}$.
} 
Table 3: Summary Statistics of Credit Quantities over the Sample Period 2003m1-2016m3

\begin{tabular}{|c|c|c|c|c|c|c|}
\hline & \multicolumn{6}{|c|}{ Real Credit (million euros) } \\
\hline Country & Beginning $^{1}$ & End $^{1}$ & $\begin{array}{c}\text { Min } \\
(\mathrm{mo} / \mathrm{yr})\end{array}$ & $\begin{array}{c}\text { Max } \\
(\mathrm{mo} / \mathrm{yr})\end{array}$ & $\begin{array}{c}\text { Mean of } \\
\text { Growth } \\
\text { Rate }(\%)^{3}\end{array}$ & $\begin{array}{l}\text { Std. Dev. of } \\
\text { Growth Rate } \\
\qquad(\%)^{3}\end{array}$ \\
\hline Austria & 182409 & 198618 & $\begin{array}{c}163529 \\
(7 / 04)\end{array}$ & $\begin{array}{c}237683 \\
(7 / 12)\end{array}$ & 0.77 & 18.94 \\
\hline Belgium & 135857 & 162698 & $\begin{array}{c}122975 \\
(8 / 05) \\
\end{array}$ & $\begin{array}{c}170608 \\
(3 / 16)\end{array}$ & 2.05 & 23.68 \\
\hline Finland & 62852 & 106782 & $\begin{array}{l}62209 \\
(2 / 03)\end{array}$ & $\begin{array}{c}107364 \\
(3 / 16)\end{array}$ & 4.21 & 11.86 \\
\hline France & 1009073 & 1488875 & $\begin{array}{c}970320 \\
(3 / 04)\end{array}$ & $\begin{array}{c}1499818 \\
(1 / 16)\end{array}$ & 2.96 & 9.5 \\
\hline Germany & 1104442 & 1057124 & $\begin{array}{c}1003837 \\
(12 / 05) \\
\end{array}$ & $\begin{array}{c}1170291 \\
(1 / 09) \\
\end{array}$ & -0.28 & 9.94 \\
\hline Greece $^{2}$ & 68724 & 93049 & $\begin{array}{l}67660 \\
(3 / 03)\end{array}$ & $\begin{array}{c}129872 \\
(1 / 09)\end{array}$ & 2.52 & 21.86 \\
\hline Italy & 739792 & 923608 & $\begin{array}{c}731125 \\
(1 / 03) \\
\end{array}$ & $\begin{array}{c}1056233 \\
(8 / 11) \\
\end{array}$ & 1.78 & 10.05 \\
\hline Netherlands & 324398 & 478936 & $\begin{array}{c}320944 \\
(4 / 05) \\
\end{array}$ & $\begin{array}{c}504493 \\
(2 / 15) \\
\end{array}$ & 3.05 & 18.65 \\
\hline Portugal & 117827 & 116981 & $\begin{array}{l}115140 \\
(10 / 03)\end{array}$ & $\begin{array}{c}174689 \\
(8 / 09)\end{array}$ & -0.05 & 13.64 \\
\hline Spain & 465588 & 562645 & $\begin{array}{c}461477 \\
(1 / 03) \\
\end{array}$ & $\begin{array}{c}1079601 \\
(1 / 09) \\
\end{array}$ & 1.55 & 19.08 \\
\hline
\end{tabular}

Note: ${ }^{1}$ Average of first or last four observations of sample period. ${ }^{2}$ Sample period ends in $2016 \mathrm{~m} 02$. ${ }^{3}$ Annualized.

Real credit is defined as $\frac{N F C+N F C S E C}{C P I} * 100$ where CPI $=100$ in 2015.

Table 4: Cumulative Change in Real Loans and Real Securities during Recessions

\begin{tabular}{|l|c|c|c|c|}
\hline \multirow{2}{*}{ Country } & \multicolumn{2}{|c|}{$\begin{array}{c}\text { 2008:4-2009:6 } \\
\text { Cirst Recession }\end{array}$} & \multicolumn{2}{c|}{$\begin{array}{c}\text { Second Recession } \\
\mathbf{2 0 1 1 : 1 0 - 2 0 1 3 : 3}\end{array}$} \\
\cline { 2 - 5 } & $\begin{array}{c}\text { Change in Real } \\
\text { Loans }\end{array}$ & $\begin{array}{c}\text { Change in Real } \\
\text { Securities }\end{array}$ & $\begin{array}{c}\text { Change in Real } \\
\text { Loans }\end{array}$ & $\begin{array}{c}\text { Change in Real } \\
\text { Securities }\end{array}$ \\
\hline Austria & 14875.6 & 5735.9 & 1922.2 & -15299.0 \\
\hline Belgium & 12079.7 & 4758.2 & 56.7 & -1194.5 \\
\hline Finland & 5421.9 & 2379.0 & 4660.1 & 8053.2 \\
\hline France & 47745.4 & 65186.6 & -5036.1 & 71443.8 \\
\hline Germany & 49288.3 & -11337.1 & 7144.9 & 22733.8 \\
\hline Greece & 3393.2 & 4407.8 & -12508.9 & 1703.4 \\
\hline Italy & 36911.0 & 8450.7 & -45893.0 & 20015.8 \\
\hline Netherlands & 26441.7 & 15020.6 & 17531.8 & -6998.3 \\
\hline Portugal & 13562.6 & 8732.8 & -13534.4 & -4897.1 \\
\hline Spain & 32939.0 & -991.9 & -182496.0 & 2772.1 \\
\hline
\end{tabular}

Note: The change in real loans is defined as $\frac{\triangle N F C}{P}$, the change in real securities is defined as $\frac{\triangle N F C S E C}{P}, \triangle N F C=$ change in loans to non-financial corporations outstanding, $\triangle N F C S E C=$ change in volume of securities (issued by non-financial corporations) outstanding and $P=$ Consumer Price Index. 
In the first recession from 2008:4 to 2009:6, the cumulative change in real bank loans outstanding was positive for all countries. ${ }^{26}$ For real securities the cumulative change was positive too in all countries but Germany and Spain. It is further the case that in France and Greece the cumulative change in real securities outstanding exceeded the cumulative change in real loans over the period 2008:4-2009:6. Thus during the first recession, companies in both countries turned increasingly towards the open market to raise credit, possibly as a result of tighter lending standards imposed by banks. It is clear from these observations on changes in bank loans during the first recession, a period of heightened probability of default, that the shrinkage of the lending portfolio of banks did not occur as implied by the ACS model. The model's prediction is more on the mark with respect to securities. In all but two countries the volume of real securities outstanding expanded during the first recession.

In the second recession, the cumulative change in real bank loans outstanding was negative in France, Greece, Italy, Portugal, and Spain. The volume of price-adjusted loans decreased every month in Spain while in Greece and Portugal it did so in all but one month. The deleveraging of bank loans was particularly acute in Spain where real bank loans had decreased by $€ 182496.0$ million by the end of the second recession. ${ }^{27}$ In France, Greece, Italy, and Spain the cumulative decrease in real bank loans outstanding was accompanied by a cumulative increase in real securities outstanding. The cumulative increase in real securities in France and Italy was substantial; indeed in France the accumulation of real securities exceeded the decumulation of real loans by a factor of 14 ! In Italy dwindling bank loans were only partially compensated for, to the tune of about 45 per cent, by rising balances of real securities. In Greece and Spain, the increase in real securities outstanding pales in comparison to the decrease in real loans outstanding. In Finland and Germany bank loans did not decrease but there appeared to be a switch away from bank loans towards securities during the second recession. In Germany the cumulative change in real securities outstanding was three times the cumulative change in real bank loans outstanding. In Finland the ratio of cumulative changes in real securities to changes in real bank loans came to 1.73. In Austria, Belgium, and the Netherlands, bank loans did not decrease during the second recession while securities did.

Are these observations consistent with the ACS view of the way credit markets operate as marked fundamentals deteriorate? On balance, the data paint a mixed picture in the EMU countries. In a few countries credit aggregates did move in line with the prediction of the ACS model during the second recession. The data suggest that the substitution of one source of credit for another worked reasonably well in France and Italy as companies managed to raise credit in the bond market in the face of possibly decreasing bank support. While the volume of real loans outstanding did not decrease in Finland and Germany during the second recession, indications are that the securities market became a vital alternative source of credit in the wake of the Sovereign Debt Crisis. In contrast, it is difficult to say anything definitive

\footnotetext{
${ }^{26}$ Lending may rise during a recession because of loan commitments that require banks to provide extra funding in case a company encounters cash flow problems. Bank loan commitments were most likely less common during the second recession because of the imposition of tighter lending standards by banks after the first recession. Changes in the volume of bank loans outstanding support this view. Comparing the first column with the third column of Table 4 reveals that cumulative changes in real loans outstanding were much smaller, if positive, or were actually negative during the second recession. However, these developments are also consistent with a reduction in loan demand that may have set in because of a weakening economic outlook.

${ }^{27}$ The steep decline in real loans outstanding at the end of 2012 in Spain is due to the transfer of nonperforming loans from the domestic banking sector to SAREB, Spain's state-owned resolution agency (Banco de España (2013), Deutsche Bundesbank (2014)).
} 
about credit market developments in Spain and Greece. In Greece the securities market did not trade in eleven months of the recession; in Spain, the securities market remained too small to be a viable alternative source of credit. In Portugal both the securities and loan markets shrank in real terms, pointing to the co-existence of an all-out credit crunch and an implosion of loan demand. A similar experience befell Austria and Belgium where the cumulative change in the volume of real securities outstanding was negative but changes in real loans were positive but small.

An important result of our examination of the quantity of credit in the EMU countries is that the two components of credit, bank loans and securities, have evolved in different ways across time and countries. The absence of a common pattern over the whole sample period is brought out even more forcefully in Figure 4.
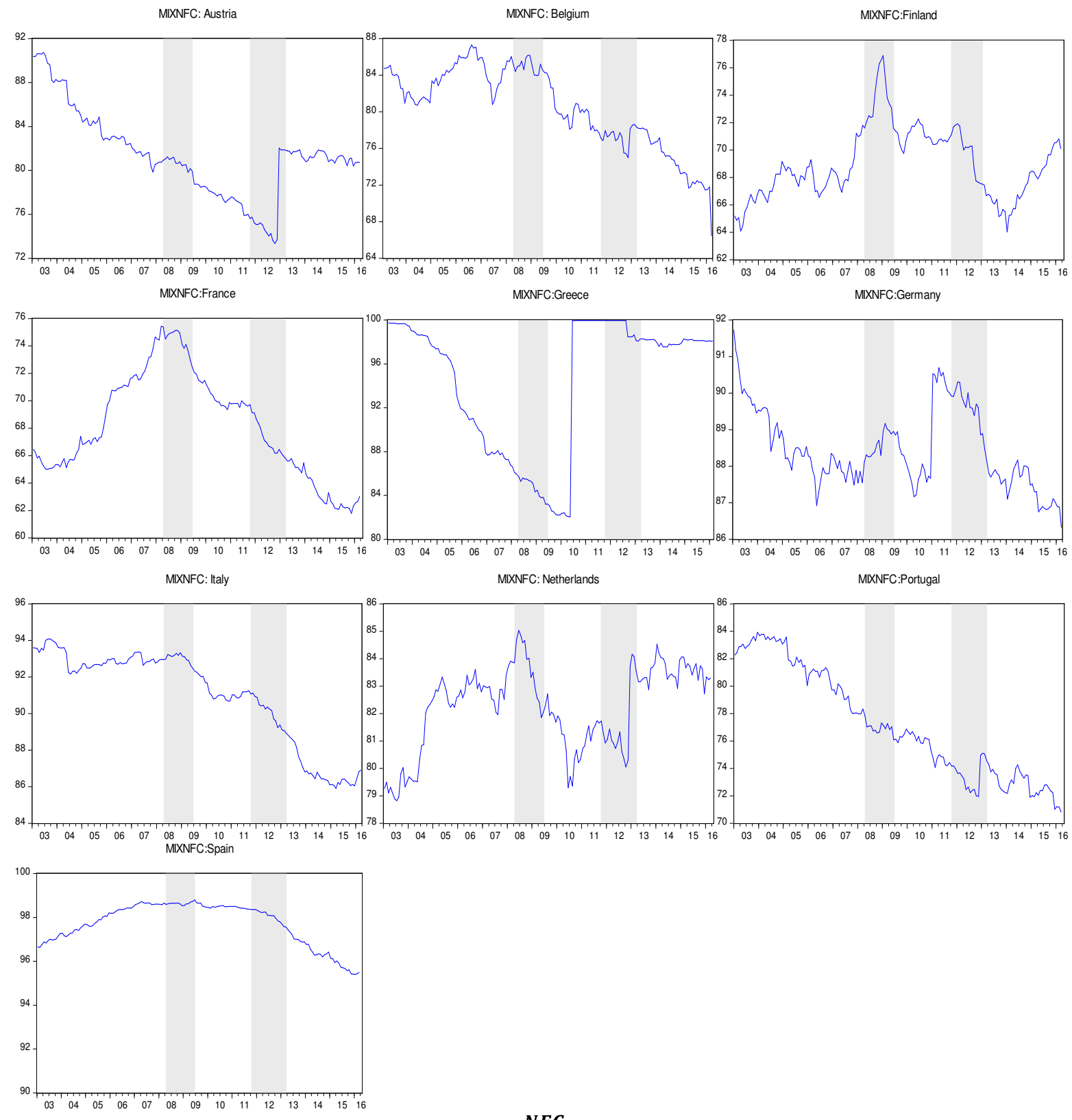

Figure 4: The Finance Mix MIXNFC $=\frac{N F C}{N F C+N F C S E C} * 100$ 
The array of graphs shows variations in the finance mix over time in each country. This finance mix is defined as the ratio of bank loans outstanding to the sum total of bank loans and securities outstanding. ${ }^{28}$ This ratio has two natural advantages. Not only does it reflect the importance of bank loans relative to securities as a source of finance but it also helps identify the existence of an aggregate 'bank lending' channel that is activated by a change in monetary policy or general financial conditions. If banks reduce their lending and firms are cut off from their traditional source of credit, firms seek to tap into the bond market to secure funding. If this scenario proves correct, then the finance mix should decrease in size.

The finance mix depicted in Figure 4 encapsulates the relative importance of bank loans and bonds as sources of external finance. Note that during the second recession the finance mix decreased to varying degrees in a number of countries, notably Finland, France, Germany, Italy, and Spain, which is possibly an indication of the shrinking relative size of the banking sector during the crisis period. Due to its potential as an informative signal about changing financial market conditions, the finance mix variable features prominently as the 'quantity-based' information variable in the forecasting equations.

\subsection{Credit prices}

A variety of factors account for the common use of price measures of credit in empirical analyses of credit markets. Market interest rates are published at high frequency intervals and are thus readily available; they are measured with great precision, react instantaneously to news, and, importantly, can easily be applied in cross-country comparisons $;{ }^{29}$ they are inextricably linked to asset prices which are inherently forward-looking and flexible. This last property means that movements in and between market interest rates are apt to provide useful information about future real economic activity rather than merely reflecting existing economic conditions.

The descriptive analysis of the price of credit in the EMU countries focuses on two annualized interest rates and a credit spread. To start with, we track the behaviour of the cost of borrowing for non-financial corporations (CoBNFC) and a general short-term measure of money market conditions in the EMU. ${ }^{30}$ The difference between the two interest rates is the credit spread which is intended to capture the risk premium that banks charge for making loans to companies that are saddled with default risk. ${ }^{31}$

\footnotetext{
${ }^{28}$ This definition of the finance mix is similar but not identical to the one employed by Kashyap, Stein and Wilcox's (1993). They use commercial paper as the alternative to short-term bank loans. Also, our measure of bank loans is more comprehensive as it includes all loans, short and longer-term loans.

${ }^{29}$ The notion that interest rates are flexible is not universally accepted. Indeed, under asymmetric information, profit-maximizing banks engage in equilibrium credit rationing (Stiglitz and Weiss (1981)), causing the bank lending rate to become rigid. By extension, credit spreads may not capture the rationing of bank loans.

${ }^{30}$ The cost of borrowing for non-financial corporations is an interest rate series computed by the ECB. In the ECB's description, it is a narrowly defined effective rate charged by credit and other institutions on loans (A2A and $\mathrm{A} 2 \mathrm{Z}$ ), where the total is calculated by weighting the volume with a moving average. The sum of A2A and A2Z comprises loans and revolving loans, overdrafts and extended credit card debt. We also examined the behaviour of an inflation-adjusted measure of the cost of borrowing. As the inflation-adjusted measure (CoBNFC - CPI inflation) turned out to be uninformative in the forecasting exercise, we do not further describe its behaviour over the sample period here.

${ }^{31}$ The risk premium inherent in the cost of borrowing is measured relative to the risk premium of the money market rate. As shown in Table 2 we have also looked at an alternative measure of the credit spread, the ECB-
} 
Figure 5 shows the movements in the CoBNFC, the 3-month euro area-wide money market interest rate, and the spread in the ten EMU countries over the whole sample period. ${ }^{32}$ Note the surprising differences in the nominal borrowing rates between the individual countries at the beginning of the sample period. The CoBNFC was higher in Germany, for instance, than in Spain and about equal to the rate in Italy. France and Finland had the lowest CoBNFC while Greece and Portugal had the highest. Scrutinizing the behaviour of the spread in Figure 5 and Table 5 is equally intriguing. Unlike in the case of credit quantities, the spread adheres to a far more cohesive pattern in all countries. For instance, the spread decreases in all countries in the initial stage of the sample period, falling below 50 basis points in Austria, Finland, France, and the Netherlands. Another example is the level of the spread observed at the beginning of the sample period relative to that at the end. Figure 6 shows that the spread had risen considerably in the majority of the countries by the end of the sample period, particularly in countries on the southern flank (except Italy), Finland, France, and Belgium. A third shared feature is that the spread rises during recessions in all countries as would be expected given that the probability of default increases during an economic downturn. A comparison of the minimums and maximums of the spread recorded during recessions is also revealing. As Figure 7 illustrates, both the minimums and maximums of the spread were higher during the second recession than during the first. Indeed, the minimum of the spread increased considerably more in all countries during the second recession than during the first, a clear indication that the European Debt Crisis led to elevated risk premiums throughout the monetary union. Lenders demanded higher compensation for risky loans because the spectre of sovereign debt default had infected financial markets, particularly on the southern periphery.

Yet there are also stark differences between the country-specific spreads. Figure 8 shows a clear difference between, loosely speaking, North (A, B, D, FI, F, NL) and South (E, GR, I, P) over the period 2003-2016: the standard deviation of the spread is appreciably higher in the countries on the southern flank than in the other EMU countries where the standard deviation is tightly clustered around 0.45 per cent. The mean of the spread in Portugal and Greece at 3.48 per cent and 4.02 per cent, respectively, was roughly 200-250 basis points higher than the mean of the spread averaged across the North of 1.54 per cent. A final difference concerns the behaviour of the spread in the aftermath of the second recession. Turning back to Figure 5 , we observe that at the end of the sample period the spread had decreased by approximately 200 basis points in Portugal, 130 basis points in Italy, 100 basis points in Spain, and nearly 100 basis points in Greece while the spread in the northern countries remained quite constant throughout the post-recession interval.

\footnotetext{
spread, which is based on the swap rate. But since the correlation of the spread and the ECB-spread is very high - it ranges from a low of 0.87 in France to a high of 0.99 in Spain - our discussion of price-based measures of credit in this section will concentrate on the spread. The ECB-spread figures in the construction of the regression framework in Section 4.3.

${ }^{32}$ The level of interest rates is measured along the left-hand vertical axis while the spread is measured along the right-hand vertical axis.
} 

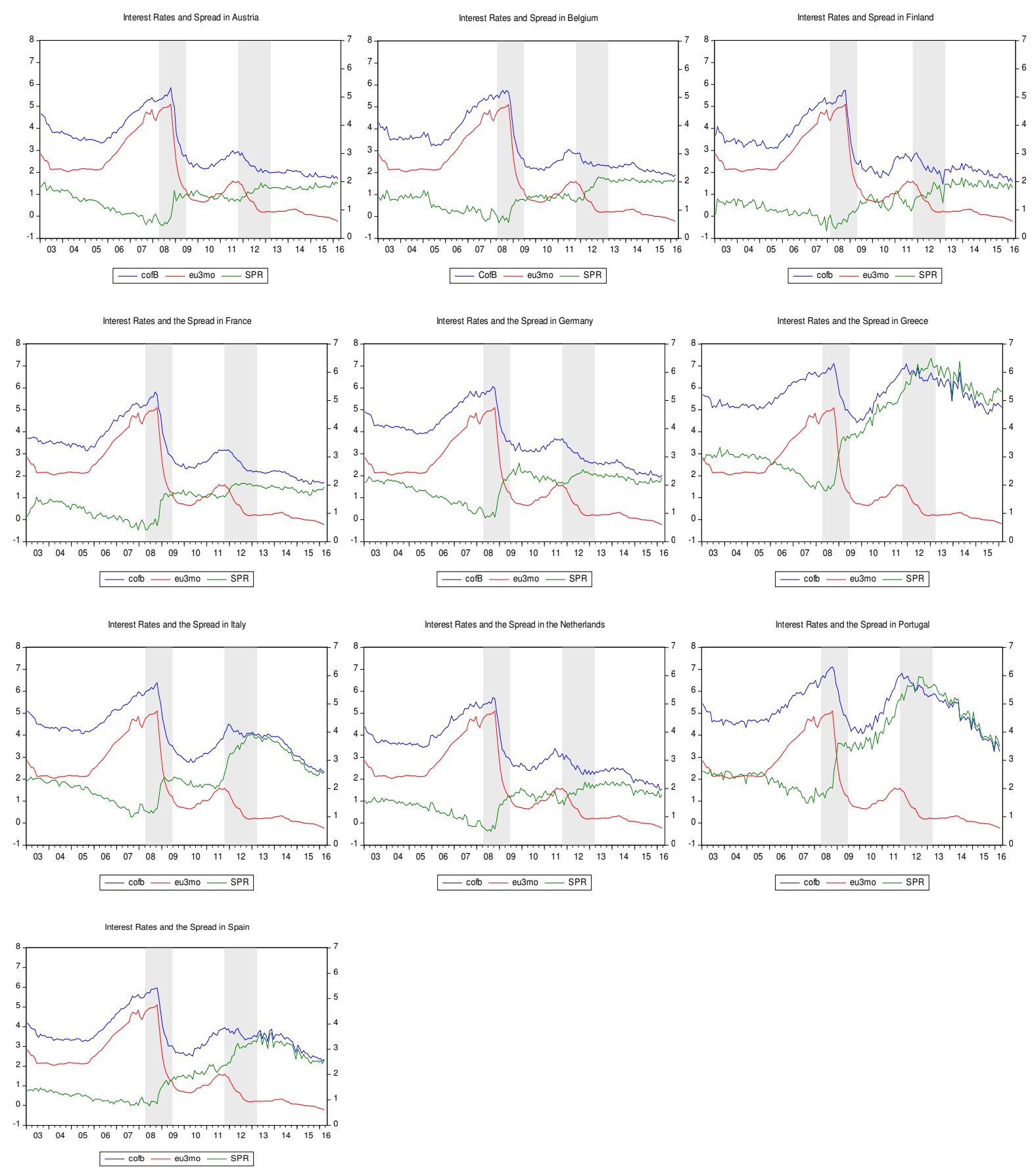

Figure 5: Market Interest Rates and the Spread (\%)

Note CofB $=$ Cost of Borrowing, eu3mo $=3$-month Money Market Rate, $\mathrm{SPR}=$ Spread . 
Table 5: Summary Statistics for the Credit Spread over the Sample Period 2003m1-2016m3 (\%)

\begin{tabular}{|l|c|c|c|c|c|c|c|c|}
\hline Country & Beginning & End & Min & Max & Mean & $\begin{array}{c}\text { Std. Dev. } \\
\left(\begin{array}{c}\text { Min,Max) } \\
\text { Rec. 1 }\end{array}\right.\end{array}$ & $\begin{array}{c}\text { (Min,Max) } \\
\text { Rec. 2 }\end{array}$ \\
\hline Austria & 1.82 & 1.93 & 0.45 & 1.99 & 1.43 & 0.40 & $(0.45,1.68)$ & $(1.30,1.95)$ \\
\hline Belgium & 1.44 & 2.12 & 0.55 & 2.18 & 1.48 & 0.44 & $(0.55,1.39)$ & $(1.28,2.18)$ \\
\hline Finland & 0.85 & 1.79 & 0.26 & 2.14 & 1.30 & 0.45 & $(0.33,1.32)$ & $(1.11,1.98)$ \\
\hline France & 0.89 & 1.93 & 0.41 & 2.07 & 1.44 & 0.46 & $(0.42,1.70)$ & $(1.59,2.07)$ \\
\hline Germany & 2.09 & 2.25 & 0.84 & 2.78 & 1.99 & 0.44 & $(0.84,2.38)$ & $(2.04,2.55)$ \\
\hline Greece & 2.87 & 5.31 & 1.80 & 6.49 & 4.02 & 1.41 & $(1.80,3.74)$ & $(5.31,6.49)$ \\
\hline Italy & 2.27 & 2.56 & 0.99 & 3.93 & 2.38 & 0.78 & $(1.13,2.40)$ & $(2.55,3.93)$ \\
\hline Netherlands & 1.57 & 1.78 & 0.49 & 2.25 & 1.58 & 0.44 & $(0.49,1.72)$ & $(1.42,2.22)$ \\
\hline Portugal & 2.61 & 3.50 & 1.48 & 5.96 & 3.48 & 1.31 & $(1.67,3.63)$ & $(5.14,5.96)$ \\
\hline Spain & 1.36 & 2.57 & 0.76 & 3.65 & 1.93 & 0.87 & $(0.76,1.80)$ & $(2.36,3.33)$ \\
\hline
\end{tabular}

Note: ${ }^{1}$ Sample period ends $2016 \mathrm{~m} 2$.

Recession 1: 2008m4-2009m6. Recession 2: 2011m10-2013m3 (According to CEPR). 


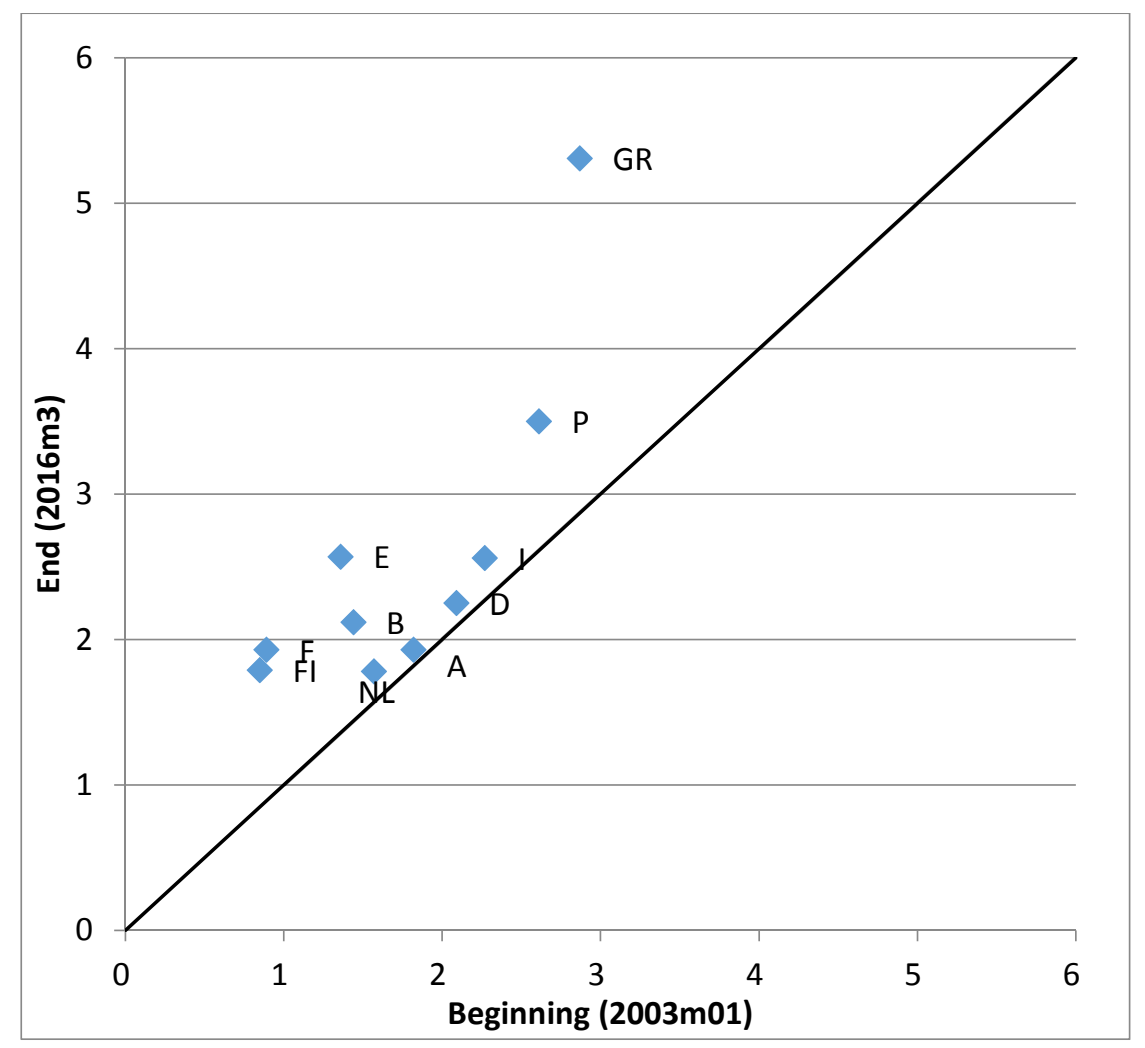

Figure 6: The Spread at the Beginning and End of the Sample Period (\%) Note: $\mathrm{A}=$ Austria, $\mathrm{B}=\mathrm{Belgium}, \mathrm{D}=$ Germany, $\mathrm{E}=$ Spain, $\mathrm{F}=$ France, FI=Finland, GR=Greece, I=Italy, $\mathrm{NL}=$ the Netherlands, $\mathrm{P}=$ Portugal.

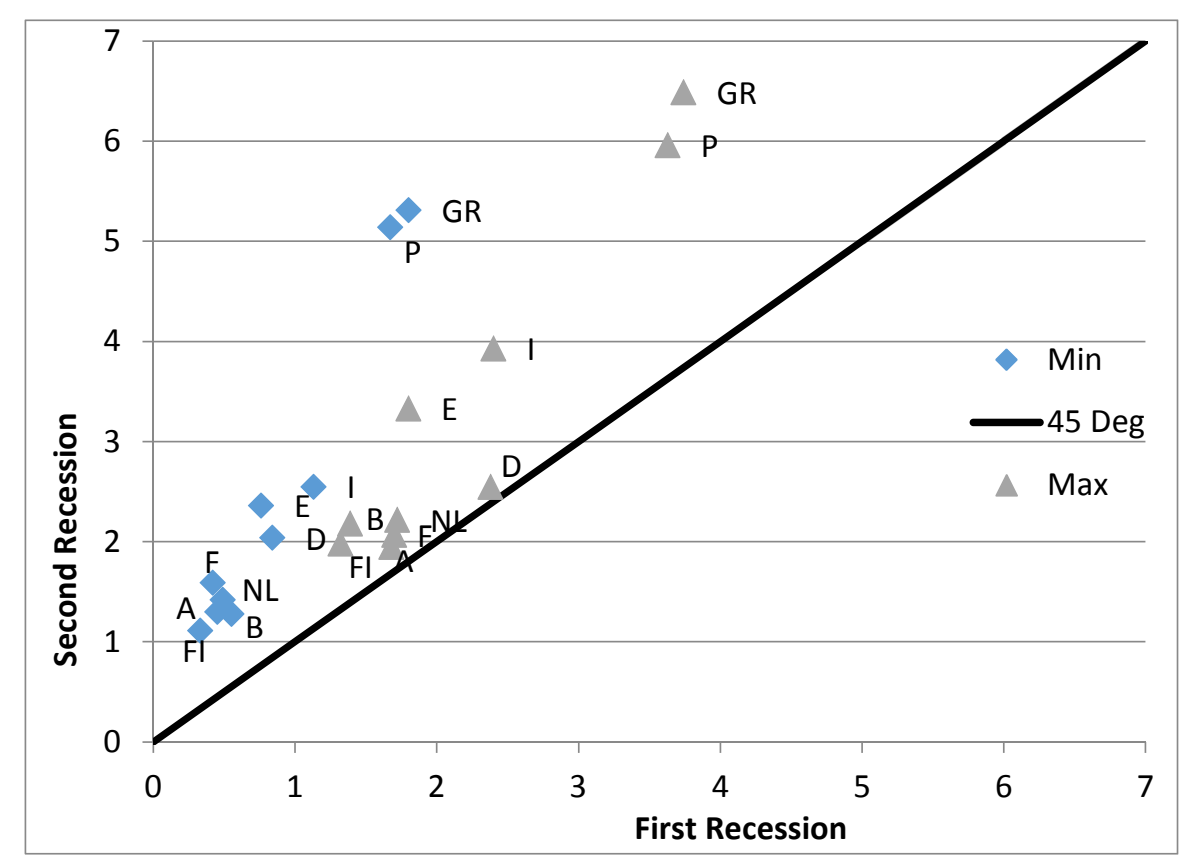

Figure 7: Spread Maximums and Minimums during Recessions (\%) 


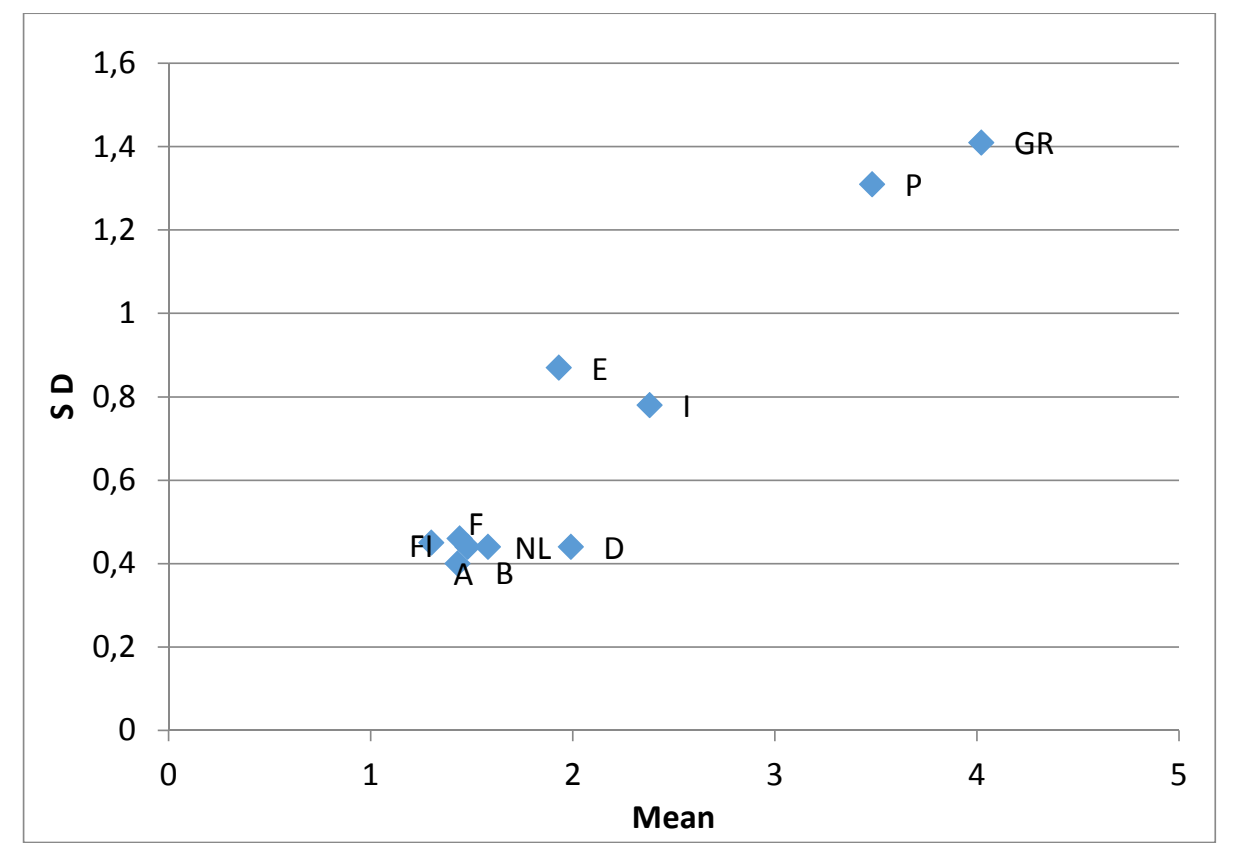

Figure 8: The Mean and Standard Deviation of the Spread (\%)

Note: $\mathrm{SD}=$ Standard Deviation.

\subsection{The specification of the forecasting equation}

The principal aim of this paper is to investigate whether price-based or quantity-based credit measures are better at predicting in-sample movements in economic indicators. In view of the short sample period, we adopt a rather parsimonious specification of the forecasting equation to capture the effect of lagged changes in the financial indicators on current economic activity: ${ }^{33}$

$$
\Delta y_{t}=a_{0}+\sum_{i=1}^{l} a_{i} \Delta y_{t-i}+\sum_{i=1}^{m} b_{i} \Delta s p r_{t-i}+\sum_{i=1}^{n} c_{i} \Delta m i x_{t-i}+e_{t}
$$

where $\Delta y_{t}=$ growth rate of a measure of economic activity $Y_{t}$ (annualized) in period $t$ :

$$
\Delta y_{t}=1200 \log \left(\frac{Y_{t}}{Y_{t-1}}\right)
$$

$\Delta s p r_{t-i}=$ first difference of the spread in period $t-j$ where the spread is defined as the difference between the cost of borrowing for NFC (non-financial corporations) and the euro-area 3-month money market interest rate.

\footnotetext{
${ }^{33}$ Given the short sample interval, we do not consider various forecasting horizons such as 3, 6 or 12 months. The sample period spans only 13 years which makes discussions about the longer-run behaviour of economic indicators and financial information variables somewhat problematic. For this reason we decided not to test for cointegration of the variables in question. Prior to carrying out the forecasting exercise, we examined the temporal properties of the time series data. Employing Augmented Dickey Fuller tests, we found that with one exception (the turnover of capital goods series in Portugal) the null hypothesis of non-stationarity could not be rejected. As a result, all but one data series were first-differenced.
} 
$\Delta m i x_{t-i}=$ first difference of the mix in period $t-j$ where the mix is defined as follows: mix $=\frac{\text { Loans to NFC }}{\text { Loans to NFC }+ \text { Securities issued by NFC }}$

A second specification of the forecasting equation replaces $\Delta s p r$ with $\Delta E C B s p r$. This alternative definition of the credit spread is defined as the difference between the cost of borrowing for NFC and the swap rate. Importantly, this definition of the credit spread uses a measure of the cost of borrowing that applies only to new loans. A precise definition of this series can be found in Table 2 .

Standard testing procedures are followed to determine the predictive content of the credit spreads and the finance mix for four indicators of economic activity. In the first instance, we test the hypothesis that $m(n)$ lags of the change in the credit spread (finance mix) are jointly insignificant by means of an F-test. ${ }^{34,35}$

We also employ a t-test to verify the hypothesis that the sum of the coefficients (SoC) $b_{i}\left(c_{i}\right) i=1,2, \ldots m(n)$ on $m(n)$ lags of the credit spread (finance mix) equals zero. The purpose of the "sign" test is to establish the direction of causality and to measure the marginal effect of past changes in the financial market indicator on the economic indicator. Drawing out the implications of the theoretical framework of Section 2, we would expect the sign on the sum of the coefficients on the credit spread to be negative for Industrial Production, Retail Sales, and Capital Turnover but positive for the Rate of Unemployment. Just the reverse is the case for the expected sign on the sum of the coefficients of the finance mix variable with the sign being positive for Industrial Production, Retail Sales and Capital Turnover but negative for the Rate of Unemployment.

\subsection{Econometric results}

Tables 6 and 7 show the results of the examination of the in-sample forecasting performance of the financial information variables for the four economic indicators in all countries. For each economic indicator the tables report the following information:

- The lag length of the estimated forecasting equation as determined by the Akaike information criterion.

- The goodness of fit measure $\bar{R}^{2}$.

- The F-test statistic of the exclusion restriction; the number in brackets is the probability that the null hypothesis can be rejected. The pair of numbers in italics at the top of the cell applies to the credit spread while the pair of numbers at the bottom applies to the finance mix.

- The t-test statistic for the hypothesis that the coefficients on the lags of the financial indicator sum to zero. The pair of numbers reported is the sum of the coefficients and the associated standard error (in parentheses). The entries at the top of the cell in italics refer to the credit spread while the entries at the bottom refer to the finance mix.

\footnotetext{
${ }^{34}$ Because the standard errors are computed in accordance with Newey and West (1987), the computed F-statistic does not have the standard finite sample properties. Hence the reported F-statistics are indicative only.

${ }^{35}$ When appropriate, the forecasting equations include indicator variables to mark significant exogenous events such as the reclassification of loans in Austria in 2004 or in Spain in 2012. No indicator variable is included in the forecasting equation for Greece as the changes in the finance mix were due to economic events.
} 
Table 6: The Effects of the Spread and the Finance Mix on Measures of Economic Activity: 2004:02-2016:m03

\begin{tabular}{|c|c|c|c|c|c|c|c|c|c|c|c|c|}
\hline & \multicolumn{4}{|c|}{ Industrial Production } & \multicolumn{4}{|c|}{ Retail Sales } & \multicolumn{4}{|c|}{ Unemployment Rate } \\
\hline & Lags $(1, m, n)$ & $\bar{R}^{2}$ & $\mathrm{~F}$ [p-val] & SoC & $\operatorname{Lags}(1, m, n)$ & $\bar{R}^{2}$ & $\mathrm{~F}$ [p-val] & SoC & $\operatorname{Lags}(1, m, n)$ & $\bar{R}^{2}$ & $\mathrm{~F}[\mathrm{p}$-val] & SoC \\
\hline Austria & $(18,12,12)$ & 0.89 & $\begin{array}{l}2.52^{* * * *} \\
{[0.01]} \\
0.58 \\
{[0.85]}\end{array}$ & $\begin{array}{l}-24.47^{* *} \\
(11.19) \\
-0.90^{*} \\
(0.55)\end{array}$ & $(24,18,24)$ & 0.57 & $\begin{array}{l}1.84^{* *} \\
{[0.04]} \\
1.35 \\
{[0.17]}\end{array}$ & $\begin{array}{l}0.17 \\
(5.55) \\
-2.51^{\text {*** }} \\
(0.81)\end{array}$ & $(18,18,18)$ & 0.54 & $\begin{array}{l}1.53^{*} \\
{[0.10]} \\
0.92 \\
{[0.55]}\end{array}$ & $\begin{array}{l}0.44 \\
(0.45) \\
0.059^{*} \\
(0.034)\end{array}$ \\
\hline Belgium & $(12,12,12)$ & 0.79 & $\begin{array}{l}1.01 \\
{[0.44]} \\
1.46 \\
{[0.15]}\end{array}$ & $\begin{array}{l}-28.81^{\text {*** }} \\
(11.63) \\
-1.87 \\
(1.20)\end{array}$ & $(12,12,12)$ & 0.58 & $\begin{array}{l}0.83 \\
{[0.62]} \\
1.36 \\
{[0.19]}\end{array}$ & $\begin{array}{l}-3.97 \\
(3.43) \\
0.58 \\
(0.66)\end{array}$ & $(12,12,12)$ & 0.60 & $\begin{array}{l}1.49 \\
{[0.14]} \\
\\
0.68 \\
{[0.77]}\end{array}$ & $\begin{array}{l}1.01^{* * *} \\
(0.51) \\
0.04 \\
(0.05)\end{array}$ \\
\hline Finland & $(12,12,12)$ & 0.87 & $\begin{array}{l}1.78^{*} \\
{[0.06]} \\
2.73^{* * *} \\
{[0.01]}\end{array}$ & $\begin{array}{l}-58.84^{* * *} \\
(16.60) \\
-5.99^{* * *} \\
(2.09)\end{array}$ & $(12,12,12)$ & 0.77 & $\begin{array}{l}0.17 \\
{[0.99]} \\
0.62 \\
{[0.82]}\end{array}$ & $\begin{array}{c}-0.99 \\
(8.29) \\
\\
-0.99 \\
(0.77)\end{array}$ & $(18,12,12)$ & 0.86 & $\begin{array}{l}1.02 \\
{[0.44]} \\
0.87 \\
{[0.57]}\end{array}$ & $\begin{array}{l}0.24 \\
(0.20) \\
0.03 \\
(0.02)\end{array}$ \\
\hline France & $(24,18,18)$ & 0.89 & $\begin{array}{l}1.23 \\
{[0.26]} \\
\\
1.02 \\
{[0.45]}\end{array}$ & $\begin{array}{l}-13.10 \\
(12.64) \\
-1.06 \\
(1.15)\end{array}$ & $(12,12,12)$ & 0.64 & $\begin{array}{l}1.95^{* *} \\
{[0.04]} \\
1.97^{* *} \\
{[0.03]}\end{array}$ & $\begin{array}{l}-5.15^{*} \\
(2.77) \\
\\
-0.45 \\
(0.62)\end{array}$ & $(12,12,12)$ & 0.49 & $\begin{array}{l}2.12^{* *} \\
{[0.02]} \\
0.49 \\
{[0.91]}\end{array}$ & $\begin{array}{l}0.28 \\
(0.37) \\
\\
-0.04 \\
(0.04)\end{array}$ \\
\hline Germany & $(24,12,12)$ & 0.95 & $\begin{array}{l}1.31 \\
{[0.24]} \\
1.96^{* *} \\
{[0.04]}\end{array}$ & $\begin{array}{l}7.97 \\
(11.65) \\
-5.87 \\
(3.75)\end{array}$ & $(24,12,12)$ & 0.59 & $\begin{array}{l}1.45 \\
{[0.16]} \\
\\
0.67 \\
{[0.77]}\end{array}$ & $\begin{array}{l}-3.87 \\
(3.48) \\
\\
-1.76 \\
(1.35)\end{array}$ & $(24,18,18)$ & 0.96 & $\begin{array}{l}1.71^{* *} \\
{[0.05]} \\
1.35 \\
{[0.18]}\end{array}$ & $\begin{array}{l}0.04 \\
(0.06) \\
-0.029^{*} \\
(0.016)\end{array}$ \\
\hline
\end{tabular}


Table 6: The Effects of the Spread and the Finance Mix on Measures of Economic Activity: 2004:02-2016:m03 (cont.)

\begin{tabular}{|c|c|c|c|c|c|c|c|c|c|c|c|c|}
\hline & \multicolumn{4}{|c|}{ Industrial Production } & \multicolumn{4}{|c|}{ Retail Sales } & \multicolumn{4}{|c|}{ Unemployment Rate } \\
\hline & $\operatorname{Lags}(1, m, n)$ & $\bar{R}^{2}$ & $\mathrm{~F}$ [p-val] & SoC & $\operatorname{Lags}(1, m, n)$ & $\bar{R}^{2}$ & $\mathrm{~F}[\mathrm{p}$-val] & SoC & $\operatorname{Lags}(1, m, n)$ & $\bar{R}^{2}$ & $\mathrm{~F}[\mathrm{p}$-val $]$ & SoC \\
\hline Greece & $(12,12,12)$ & 0.58 & $\begin{array}{l}1.29 \\
{[0.23]} \\
1.13 \\
{[0.34]} \\
\end{array}$ & $\begin{array}{l}-7.68 \\
(7.23) \\
-1.08^{* * *} \\
(0.31)\end{array}$ & $(24,12,18)$ & 0.88 & $\begin{array}{l}0.76 \\
{[0.68]} \\
1.96^{* *} \\
{[0.02]} \\
\end{array}$ & $\begin{array}{l}-2.96 \\
(7.37) \\
-1.72^{* * *} \\
(0.49) \\
\end{array}$ & $(24,12,24)$ & 0.69 & $\begin{array}{l}1.77^{*} \\
{[0.07]} \\
1.93^{* * *} \\
(0.01) \\
\end{array}$ & $\begin{array}{l}0.78^{* * * *} \\
(0.30) \\
\\
0.27^{* * *} \\
(0.06)\end{array}$ \\
\hline Italy & $(24,12,24)$ & 0.95 & $\begin{array}{l}1.64^{*} \\
{[0.1]} \\
1.85^{* *} \\
{[0.02]}\end{array}$ & $\begin{array}{l}-7.35^{*} \\
(4.49) \\
\\
0.18 \\
(2.73) \\
\end{array}$ & $(18,12,12)$ & 0.84 & $\begin{array}{l}1.45 \\
{[0.16]} \\
1.00 \\
{[0.45]}\end{array}$ & $\begin{array}{l}-1.95 \\
(2.08) \\
0.20 \\
(1.10) \\
\end{array}$ & $(12,12,12)$ & 0.20 & $\begin{array}{l}1.97^{* * *} \\
{[0.03]} \\
0.49 \\
{[0.92]}\end{array}$ & $\begin{array}{l}1.68^{* * * *} \\
(0.47) \\
-0.29 \\
(0.26)\end{array}$ \\
\hline Netherlands & $(18,12,12)$ & 0.62 & $\begin{array}{l}0.70 \\
{[0.75]} \\
0.52 \\
{[0.90]}\end{array}$ & $\begin{array}{l}-7.81 \\
(12.94) \\
0.07 \\
(2.24) \\
\end{array}$ & $(24,12,24)^{\#}$ & 0.87 & $\begin{array}{l}2.15^{* *} \\
{[0.02]} \\
1.73^{* *} \\
{[0.04]}\end{array}$ & $\begin{array}{l}-26.04^{* * *} \\
(9.88) \\
1.80 \\
(1.12)\end{array}$ & $(18,12,18)$ & 0.54 & $\begin{array}{l}2.28^{* * * *} \\
{[0.01]} \\
1.94^{* *} \\
{[0.02]}\end{array}$ & $\begin{array}{l}0.96^{* * * *} \\
(0.25) \\
0.02 \\
(0.07) \\
\end{array}$ \\
\hline Portugal & $(12,12,18)$ & 0.64 & $\begin{array}{l}1.86^{* *} \\
{[0.05]} \\
1.04 \\
{[0.43]}\end{array}$ & $\begin{array}{l}-14.82^{* *} \\
(6.50) \\
-2.90 \\
(4.60)\end{array}$ & $(12,12,12)$ & 0.75 & $\begin{array}{l}0.95 \\
{[0.50]} \\
\\
1.51 \\
{[0.13]}\end{array}$ & $\begin{array}{l}-2.21 \\
(2.98) \\
5.42^{* * *} \\
(1.67)\end{array}$ & $(12,12,18)$ & 0.34 & $\begin{array}{l}1.21 \\
{[0.29]} \\
0.59 \\
{[0.90]}\end{array}$ & $\begin{array}{l}0.82^{* * * *} \\
(0.33) \\
-0.29 \\
(0.26)\end{array}$ \\
\hline Spain & $(12,12,12)$ & 0.92 & $\begin{array}{l}1.02 \\
{[0.43]} \\
0.81 \\
{[0.64]}\end{array}$ & $\begin{array}{l}-7.06 \\
(9.01) \\
1.46 \\
(3.17)\end{array}$ & $(18,12,12)$ & 0.92 & $\begin{array}{l}1.79^{* *} \\
{[0.05]} \\
0.76 \\
{[0.69]}\end{array}$ & $\begin{array}{l}-14.48 \\
(9.63) \\
1.48 \\
{[3.93]}\end{array}$ & $(12,12,12)$ & 0.85 & $\begin{array}{l}0.90 \\
{[0.55]} \\
1.00 \\
{[0.46]}\end{array}$ & $\begin{array}{l}-0.41 \\
(0.60) \\
0.16 \\
(0.16)\end{array}$ \\
\hline
\end{tabular}


Table 6: The Effects of the Spread and the Finance Mix on Measures of Economic Activity: 2004:02-2016:m03 (cont.)

\begin{tabular}{|c|c|c|c|c|c|c|c|c|c|}
\hline & \multicolumn{4}{|c|}{ Turnover of Capital Goods } & & \multicolumn{4}{|c|}{ Turnover of Capital Goods } \\
\hline & Lags $(1, m, n)$ & $\bar{R}^{2}$ & $\mathrm{~F}$ [p-val] & SoC & & $\operatorname{Lags}(1, \mathrm{~m}, \mathrm{n})$ & $\bar{R}^{2}$ & $\mathrm{~F}$ [p-val] & SoC \\
\hline $\begin{array}{l}\text { Austria } \\
(2007: 07- \\
2016: 03)\end{array}$ & $(18,12,12)$ & 0.80 & $\begin{array}{l}1.69^{*} \\
{[0.09]} \\
1.11 \\
{[0.36]}\end{array}$ & $\begin{array}{l}-33.54 \\
(23.20) \\
0.87 \\
(1.55)\end{array}$ & Greece & $(24,12,12) \#$ & 0.60 & $\begin{array}{l}1.80^{* * *} \\
{[0.05]} \\
1.46 \\
{[0.15]}\end{array}$ & $\begin{array}{l}-56.25^{* * *} \\
(19.56) \\
0.87 \\
(1.89)\end{array}$ \\
\hline Belgium & $(18,12,12)$ & 0.77 & $\begin{array}{l}0.89 \\
{[0.56]} \\
2.07^{* *} \\
{[0.03]}\end{array}$ & $\begin{array}{l}-37.68^{*} \\
(20.18) \\
-0.56 \\
(2.60)\end{array}$ & Italy & $(12,12,12)$ & 0.66 & $\begin{array}{l}2.49^{* * * *} \\
{[0.01]} \\
1.82^{* *} \\
{[0.02]}\end{array}$ & $\begin{array}{l}-34.29^{* *} \\
(16.56) \\
18.21^{* *} \\
(9.10)\end{array}$ \\
\hline Finland & $(18,12,12)$ & 0.73 & $\begin{array}{l}1.14 \\
{[0.34]} \\
1.61^{*} \\
{[0.10]}\end{array}$ & $\begin{array}{l}-108.02^{* * *} \\
(39.74) \\
-9.17^{* *} \\
(4.66)\end{array}$ & Netherlands & $(24,12,18)$ & 0.74 & $\begin{array}{l}1.41 \\
{[0.18]} \\
1.09 \\
{[0.38]}\end{array}$ & $\begin{array}{l}-78.37^{* * *} \\
(30.57) \\
7.80 \\
(7.22)\end{array}$ \\
\hline France & $(12,12,12)$ & 0.64 & $\begin{array}{l}2.77^{2 * *} \\
{[0.01]} \\
0.61 \\
{[0.84]}\end{array}$ & $\begin{array}{l}-54.73^{* * *} \\
(16.24) \\
-1.25 \\
(2.16)\end{array}$ & Portugal $^{1}$ & $(12,12,12)$ & 0.36 & $\begin{array}{l}0.79 \\
{[0.66]} \\
1.58^{*} \\
{[0.10]}\end{array}$ & $\begin{array}{l}-11.05 \\
(8.04) \\
-7.70 \\
(9.75)\end{array}$ \\
\hline Germany & $(24,12,12)$ & 0.89 & $\begin{array}{l}1.61^{*} \\
{[0.10]} \\
1.45 \\
{[0.16]}\end{array}$ & $\begin{array}{l}-15.05 \\
(19.82) \\
-13.66^{* *} \\
6.58)\end{array}$ & Spain & $(24,12,12)$ & 0.79 & $\begin{array}{l}1.00 \\
{[0.46]} \\
1.07 \\
{[0.39]}\end{array}$ & $\begin{array}{l}-42.04^{* *} \\
(20.71) \\
5.05 \\
(9.18)\end{array}$ \\
\hline
\end{tabular}

Notes:

1. The turnover of the capital goods series for Portugal is clearly stationary. Hence the log of this series appears in the regression specification.

2. For Austria we also tried an adjusted finance mix that accounts for the reclassification of loans in June 2004 by way of a dummy variable. Changes in the finance mix were regressed on a dummy ( 1 in June 2004,0 otherwise) and a constant. The residuals of this regression were then used as the adjusted finance mix in the subsequent estimation of the effect of financial indicator variables on economic activity. The results obtained were very similar to those reported in Tables 6 and 7 , which are based on changes in the unadjusted mix variable.

3. Estimated specification of the regression equation (unless indicated otherwise):

$$
\Delta y_{t}=a_{0}+\sum_{i=1}^{l} a_{i} \Delta y_{t-i}+\sum_{i=1}^{m} b_{i} \Delta s p r_{t-i}+\sum_{i=1}^{n} c_{i} \Delta m i x_{t-i}+e_{t}
$$

where $\Delta y=$ first difference of an annualized measure of economic activity, $\Delta s p r=$ change of the spread between the cost of borrowing for NFC (non-financial corporations) and the euro-area 3-month money market interest rate. $\Delta m i x=\Delta\left(\frac{\text { Loans to } N F C}{\text { Loans to } N F C+\text { Securities issued by } N F C}\right)$

3. The coefficients on the dummy variables in the forecasting equation for Austria and Spain are insignificant. Hence the results reported are based on the standard specification above.

$\mathrm{F}=$ F-statistic of the null hypothesis that $m(n)$ lags of the change in the spread (finance mix) are jointly insignificant. The number in brackets is the probability that the null hypothesis can be rejected (p-value). SoC $=$ t-test of the hypothesis that the sum of the coefficients $b_{i}\left(c_{i}\right) i=1,2, \ldots m(n)$ on $m(n)$ lags of the spread (finance mix) equals zero. The number reported at the top of the cell is the sum of the coefficients. The number below in parentheses is the standard error. 
Table 7: The Effects of the ECB-Spread and the Finance Mix on Measures of Economic Activity: 2004:02-2016:m03

\begin{tabular}{|c|c|c|c|c|c|c|c|c|c|c|c|c|}
\hline & \multicolumn{4}{|c|}{ Industrial Production } & \multicolumn{4}{|c|}{ Retail Sales } & \multicolumn{4}{|c|}{ Unemployment Rate } \\
\hline & $\operatorname{Lags}(1, m, n)$ & $\bar{R}^{2}$ & $\mathrm{~F}$ [p-val] & SoC & $\operatorname{Lags}(1, m, n)$ & $\bar{R}^{2}$ & $\mathrm{~F}$ [p-val] & SoC & $\operatorname{Lags}(1, m, n)$ & $\bar{R}^{2}$ & $\mathrm{~F}[\mathrm{p}-\mathrm{val}]$ & SoC \\
\hline Austria & $(18,12,12)$ & 0.88 & $\begin{array}{l}1.87^{* * *} \\
{[0.05]} \\
0.64 \\
{[0.80]}\end{array}$ & $\begin{array}{l}-17.11 \\
(12.18) \\
-0.64 \\
(0.68)\end{array}$ & $(24,18,24)$ & 0.59 & $\begin{array}{l}2.12^{\text {***** }} \\
{[0.01]} \\
1.52^{*} \\
{[0.09]}\end{array}$ & $\begin{array}{l}-3.16 \\
(7.97) \\
-2.43^{* * *} \\
(0.76)\end{array}$ & $(18,18,18)$ & 0.54 & $\begin{array}{l}1.52^{*} \\
{[0.10]} \\
1.18 \\
{[0.30]}\end{array}$ & $\begin{array}{l}0.40 \\
(0.66) \\
\\
0.06 \\
0.04\end{array}$ \\
\hline Belgium & $(12,12,12)$ & 0.79 & $\begin{array}{l}1.17 \\
{[0.31]} \\
1.61^{*} \\
{[0.10]}\end{array}$ & $\begin{array}{l}-28.04^{* *} \\
(14.64) \\
-1.87 \\
(1.20)\end{array}$ & $(12,12,12)$ & 0.57 & $\begin{array}{l}0.78 \\
{[0.67]} \\
\\
1.35 \\
{[0.20]}\end{array}$ & $\begin{array}{l}-4.72 \\
(4.39) \\
0.61 \\
(0.70)\end{array}$ & $(12,12,12)$ & 0.63 & $\begin{array}{l}2.21^{* * * *} \\
{[0.01]} \\
1.01 \\
{[0.44]}\end{array}$ & $\begin{array}{l}0.86 \\
(0.58) \\
\\
0.04 \\
(0.05)\end{array}$ \\
\hline Finland & $(18,12,12)$ & 0.89 & $\begin{array}{l}2.00^{* *} \\
{[0.03]} \\
\\
2.76^{* * *} \\
{[0.01]}\end{array}$ & $\begin{array}{l}-62.03^{* * *} \\
(13.42) \\
-6.40^{* * *} \\
(1.87)\end{array}$ & $(12,12,12)$ & 0.77 & $\begin{array}{l}0.31 \\
{[0.99]} \\
\\
0.93 \\
{[0.52]}\end{array}$ & $\begin{array}{l}-13.03^{*} \\
(7.43) \\
-1.79^{* *} \\
(0.81)\end{array}$ & $(18,12,12)$ & 0.86 & $\begin{array}{l}0.82 \\
{[0.63]} \\
\\
0.78 \\
{[0.67]}\end{array}$ & $\begin{array}{l}0.25 \\
(0.18) \\
\\
0.03 \\
(0.02)\end{array}$ \\
\hline France & $(24,18,18)$ & 0.89 & $\begin{array}{l}1.20 \\
{[0.27]} \\
\\
0.98 \\
{[0.49]}\end{array}$ & $\begin{array}{l}-13.46 \\
(12.11) \\
-1.45 \\
(1.34)\end{array}$ & $(18,12,12)$ & 0.62 & $\begin{array}{l}1.29 \\
{[0.23]} \\
1.66^{*} \\
{[0.08]}\end{array}$ & $\begin{array}{l}-1.65 \\
(4.51) \\
-0.06 \\
(0.60)\end{array}$ & $(12,12,12)$ & 0.49 & $\begin{array}{l}1.94^{* *} \\
{[0.04]} \\
0.99 \\
{[0.47]}\end{array}$ & $\begin{array}{l}0.53 \\
(0.38) \\
\\
-0.01 \\
(0.04)\end{array}$ \\
\hline Germany & $(24,12,12)$ & 0.95 & $\begin{array}{l}1.98^{* *} \\
{[0.03]} \\
2.01^{* *} \\
{[0.03]}\end{array}$ & $\begin{array}{l}21.94 \\
(13.87) \\
-7.60^{* * *} \\
(3.08)\end{array}$ & $(24,12,12)$ & 0.59 & $\begin{array}{l}1.66^{*} \\
{[0.09]} \\
0.82 \\
{[0.63]}\end{array}$ & $\begin{array}{l}-7.17^{*} \\
(4.22) \\
-2.34^{* *} \\
(1.07)\end{array}$ & $(24,18,18)^{+}$ & 0.95 & $\begin{array}{l}0.96 \\
{[0.51]} \\
0.89 \\
{[0.59]}\end{array}$ & $\begin{array}{l}-0.12 \\
(0.11) \\
-0.028^{*} \\
(0.017)\end{array}$ \\
\hline
\end{tabular}


Table 7: The Effects of the ECB-Spread and the Finance Mix on Measures of Economic Activity: 2004:02-2016:m03 (cont.)

\begin{tabular}{|c|c|c|c|c|c|c|c|c|c|c|c|c|}
\hline & \multicolumn{4}{|c|}{ Industrial Production } & \multicolumn{4}{|c|}{ Retail Sales } & \multicolumn{4}{|c|}{ Unemployment Rate } \\
\hline & $\operatorname{Lags}(1, m, n)$ & $\bar{R}^{2}$ & $F$ [p-val] & SoC & $\operatorname{Lags}(1, m, n)$ & $\bar{R}^{2}$ & $F$ [p-val] & SoC & $\operatorname{Lags}(1, m, n)$ & $\bar{R}^{2}$ & $\mathrm{~F}[\mathrm{p}-\mathrm{val}]$ & SoC \\
\hline Greece & $(12,12,12)$ & 0.57 & $\begin{array}{l}1.23 \\
{[0.27]} \\
1.22 \\
{[0.28]}\end{array}$ & $\begin{array}{l}-7.27 \\
(8.39) \\
\\
-0.96^{* *} \\
(0.47)\end{array}$ & $(24,12,18)$ & 0.88 & $\begin{array}{l}0.66 \\
{[0.78]} \\
1.94^{* *} \\
{[0.02]}\end{array}$ & $\begin{array}{l}-7.00 \\
(9.39) \\
-1.60^{* * *} \\
(0.49)\end{array}$ & $(24,12,24)$ & 0.69 & $\begin{array}{l}1.92^{* * *} \\
{[0.05]} \\
1.90^{* *} \\
(0.02)\end{array}$ & $\begin{array}{l}1.02^{\text {***** }} \\
(0.41) \\
0.18^{* * * *} \\
(0.04)\end{array}$ \\
\hline Italy & $(24,12,24)^{+}$ & 0.95 & $\begin{array}{l}1.47 \\
{[0.15]} \\
1.84^{* *} \\
{[0.02]}\end{array}$ & $\begin{array}{c}-5.08 \\
(3.63) \\
\\
-0.75 \\
(3.05)\end{array}$ & $(18,12,12)$ & 0.84 & $\begin{array}{l}1.64^{*} \\
{[0.09]} \\
1.02 \\
{[0.44]}\end{array}$ & $\begin{array}{l}-3.52 \\
(2.31) \\
0.08 \\
(1.04)\end{array}$ & $(12,12,12)$ & 0.18 & $\begin{array}{l}1.68^{*} \\
{[0.08]} \\
0.42 \\
{[0.95]}\end{array}$ & $\begin{array}{l}1.74^{* * * *} \\
(0.63) \\
\\
-0.19 \\
(0.26)\end{array}$ \\
\hline Netherlands & $(24,12,24)$ & 0.62 & $\begin{array}{l}0.43 \\
{[0.95]} \\
\\
0.67 \\
{[0.86]}\end{array}$ & $\begin{array}{l}-2.74 \\
(16.94) \\
\\
-0.51 \\
(3.34)\end{array}$ & $(24,12,24)^{\#}$ & 0.85 & $\begin{array}{l}1.08 \\
{[0.39]} \\
1.25 \\
{[0.24]}\end{array}$ & $\begin{array}{l}-11.86 \\
(7.54) \\
0.05 \\
(1.79)\end{array}$ & $(24,12,18)$ & 0.50 & $\begin{array}{l}1.63^{*} \\
{[0.10]} \\
1.80^{* *} \\
{[0.04]}\end{array}$ & $\begin{array}{l}1.15^{\text {***\% }} \\
(0.41) \\
0.01 \\
(0.06)\end{array}$ \\
\hline Portugal & $(12,12,18)$ & 0.64 & $\begin{array}{l}1.75^{*} \\
{[0.07]} \\
0.95 \\
{[0.52]} \\
\end{array}$ & $\begin{array}{l}-15.24^{* *} \\
(6.66) \\
-1.42 \\
(4.58) \\
\end{array}$ & $(12,12,12)$ & 0.75 & $\begin{array}{l}1.08 \\
{[0.38]} \\
1.47 \\
{[0.15]}\end{array}$ & $\begin{array}{l}-2.95 \\
(3.13) \\
5.20^{* * * *} \\
(1.71)\end{array}$ & $(12,12,12)$ & 0.33 & $\begin{array}{l}1.04 \\
{[0.42]} \\
0.77 \\
{[0.68]} \\
\end{array}$ & $\begin{array}{l}0.65^{* *} \\
(0.30) \\
\\
-0.21 \\
(0.20)\end{array}$ \\
\hline Spain & $(12,12,12)$ & 0.92 & $\begin{array}{l}0.97 \\
{[0.48]} \\
\\
0.79 \\
{[0.66]}\end{array}$ & $\begin{array}{l}-3.81 \\
(6.95) \\
1.24 \\
(2.85)\end{array}$ & $(18,12,12)$ & 0.92 & $\begin{array}{l}1.93^{* *} \\
{[0.04]} \\
0.85 \\
{[0.60]}\end{array}$ & $\begin{array}{l}-9.87 \\
(6.77) \\
\\
-0.64 \\
{[3.06]}\end{array}$ & $(12,12,12)$ & 0.85 & $\begin{array}{l}1.09 \\
{[0.37]} \\
\\
1.05 \\
{[0.41]}\end{array}$ & $\begin{array}{l}-0.23 \\
(0.36) \\
\\
0.15 \\
(0.17)\end{array}$ \\
\hline
\end{tabular}


Table 7: The Effects of the ECB-Spread and the Finance Mix on Measures of Economic Activity: 2004:02-2016:m03 (cont.)

\begin{tabular}{|l|l|l|l|l|}
\hline & \multicolumn{3}{|c|}{ Turnover of Capital Goods } \\
\hline & Lags(l,m,n) & $\bar{R}^{2}$ & $\mathrm{~F}$ [p-val] & SoC \\
\hline Austria & $(24,12,12)$ & 0.83 & 1.55 & -22.75 \\
& & & {$[0.14]$} & $(30.91)$ \\
& & & 1.12 & 1.31 \\
& & & {$[0.37]$} & $(2.48)$ \\
\hline Belgium & $(18,12,12)$ & 0.78 & 1.02 & -28.55 \\
& & & {$[0.43]$} & $(21.80)$ \\
& & & $2.38^{* * *}$ & -0.48 \\
& & & {$[0.01]$} & $(2.52)$ \\
\hline Finland & $(18,12,18)$ & 0.72 & 1.02 & $-95.61^{* *}$ \\
& & & {$[0.44]$} & $(43.63)$ \\
& & & 0.93 & $-9.62^{* *}$ \\
& & & {$[0.55]$} & $(5.25)$ \\
\hline France & $(24,12,12)$ & 0.61 & 0.98 & $-21.57^{*}$ \\
& & & {$[0.47]$} & $(11.64)$ \\
& & & 0.58 & 0.92 \\
& & & {$[0.56]$} & $(1.68)$ \\
\hline Germany & $(24,12,12)$ & 0.89 & 1.54 & 20.70 \\
& & & {$[0.12]$} & $(25.50)$ \\
& & & $1.78^{*}$ & $-17.23^{* *}$ \\
& & & {$[0.06]$} & $(6.53)$ \\
\hline
\end{tabular}

\begin{tabular}{|l|l|l|l|l|}
\hline & \multicolumn{4}{|c|}{ Turnover of Capital Goods } \\
\hline & Lags(l,m,n) & $\bar{R}^{2}$ & $\mathrm{~F}$ [p-val] & SoC \\
\hline Greece & $(24,12,12) \#$ & 0.58 & 1.50 & $-61.00^{* * * *}$ \\
& & & {$[0.14]$} & $(24.59)$ \\
& & & 1.55 & 2.06 \\
& & & {$[0.12]$} & $(2.11)$ \\
\hline Italy & $(12,12,12)^{+}$ & 0.65 & $2.01^{* *}$ & -20.16 \\
& & & {$[0.03]$} & $(12.94)$ \\
& & & $1.59^{*}$ & 14.45 \\
& & & {$[0.10]$} & $(9.63)$ \\
\hline Netherlands & $(24,12,18)$ & 0.73 & 1.17 & -50.06 \\
& & & {$[0.31]$} & $(42.22)$ \\
& & & 1.15 & 3.75 \\
& & & {$[0.33]$} & $(7.84)$ \\
\hline Portugal & & 0.36 & 0.83 & -10.33 \\
& $(12,12,12)$ & & {$[0.62]$} & $(8.46)$ \\
& & & $1.69^{*}$ & -8.63 \\
& & & {$[0.10]$} & $(9.50)$ \\
\hline Spain & & 0.79 & 0.76 & -22.27 \\
& & & {$[0.69]$} & $(15.54)$ \\
& $(24,12,12)$ & & 0.91 & 2.17 \\
& & & {$[0.66]$} & $(9.10)$ \\
\hline & & & &
\end{tabular}

Notes:

1. The turnover of the capital goods series for Portugal is clearly stationary. Hence the log of this series appears in the regression specification.

2. Estimated specification of the regression equation (unless indicated otherwise):

$\Delta y_{t}=a_{0}+\sum_{i=1}^{l} a_{i} \Delta y_{t-i}+\sum_{i=1}^{m} b_{i} \Delta E C B s p r_{t-i}+\sum_{i=1}^{n} c_{i} \Delta m i x_{t-i}+e_{t}$

where $\Delta y=$ first difference of an annualized measure of economic activity

$\triangle E C B s p r=$ change of the weighted lending spread between the MIR rate for new NFC (non-financial corporation) loans and the swap rate (maturity adjusted).

$\Delta$ mix $=\Delta\left(\frac{\text { Loans to } N F C}{\text { Loans to } N F C+\text { Securities issued by NFC }}\right)$

$\mathrm{F}=$ F-statistic of the null hypothesis that $m(n)$ lags of the change in the ECB spread (finance mix) are jointly insignificant. The number in brackets is the probability that the null hypothesis can be rejected (p-value). SoC $=\mathrm{t}$-test of the hypothesis that the sum of the coefficients $b_{i}\left(c_{i}\right) i=1,2, \ldots m(n)$ on $m(n)$ lags of the ECB spread (finance mix) equals zero. The number reported at the top of the cell is the sum of the coefficients. The number below in parentheses is the standard error. All variables were tested for non-stationarity. Non-stationary variables have been differenced.

${ }^{\#}$ Estimated specification includes a deterministic time trend. 
Inspection of Table 6 reveals that lagged increases in the spread had the expected negative marginal effect on Industrial Production in Austria, Belgium, Finland, Italy, and Portugal over the sample period. However, the predictive content and the economic significance of past realizations of the spread for this economic indicator varied considerably in strength from country to country. The forecasting power and the economic effect of the spread are very strong in Austria and Portugal, where a sustained increase of 10 basis points per period in the lags of the spread is associated with a 2.45 per cent marginal decrease in Industrial Production in Austria and a 1.48 per cent decrease in Portugal. ${ }^{36}$ For Italy the predictive power and economic significance of the spread are somewhat weaker. In Belgium only the economic impact of the spread seems to have been felt. In Finland, the predictive content of the spread is weak but the economic impact is material. In the remaining countries the spread has neither an effect on nor predictive content for Industrial Production.

The mix variable fares worse. While there is some evidence that changes in the finance mix variable predict changes in Industrial Production fairly well in Finland, Germany and Italy, the test statistic for the sum of the coefficients is either positive but below the 10 per cent critical value or, as in Finland, above it but negative. Similarly negative coefficients are reported for Greece (at the 1 per cent level of significance) and Austria (at the 10 per cent level). The negative sign is inconsistent with the notion that firms raise credit on the open market in the wake of experiencing cuts in their bank borrowing due to reduced willingness of the banks to lend.

There is only scant evidence that Retail Sales were adversely affected by past increases in the spread. The results show that lagged increases in the spread have predictive power for Retail Sales in four countries but their adverse economic impact is only felt strongly in the Netherlands and weakly in France. As far as predictive content is concerned, the results show a statistically significant relationship between the finance mix and Retail Sales in three countries, France, Greece and the Netherlands. But in none of these countries is there any evidence for a sustained positive relationship between the financial indicator and the economic indicator as implied by the theoretical model. Indeed in Greece the t-test statistic, while exceeding the critical value at the 1 per cent level of significance, is negative; a similar result obtains in Austria. The only country where the sum of coefficients on lagged values of the finance mix is positive and statistically different from zero is Portugal.

For the Rate of Unemployment we again see mixed results. It is true that the spread has predictive content in six of the ten countries, albeit to varying degrees. When complemented by the t-test for the sum of the coefficients, the results become weaker. Only in Greece, Italy and the Netherlands is there solid evidence of a positive relationship between past changes in the spread and changes in the Unemployment Rate. Notice though that the cumulative marginal effect of past increases in the spread on changes in the Unemployment Rate were positive and economically significant in Portugal and Belgium. In Greece we find a strong link between past changes in the finance mix and movements in the Unemployment Rate but

\footnotetext{
${ }^{36}$ The total effect of lagged changes in the spread on economic activity depends on the interaction of the sum of estimated coefficients with the persistence property of the variable measuring economic activity. Given the long lag structure of the estimated specification it is exceedingly difficult to determine the overall effect. The sum of coefficients reported thus captures only the marginal effect of lagged changes in the spread on current economic activity.
} 
again with an implausible sign as in the case of Industrial Production and Retail Sales. For the Netherlands, the exclusion restriction can be rejected at the 5 per cent level but the sum of coefficients is not significantly different from zero. Notice that the fit of the estimated regression is poorer for Italy and Portugal than for the other countries.

Perhaps not surprisingly, a measure of spending on investment goods produces the most favourable results for the spread as a sound financial predictor. In five of the ten countries lagged changes in the spread predict changes in the Turnover of Capital Goods. The predictive ability of the spread for this indicator of investment activity is particularly strong in France, Greece and Italy but weaker in Austria and Germany. The t-test of the cumulative marginal effect of lagged changes in the spread on changes in Capital Turnover produces the correct negative sign in all countries, though its economic impact is only felt significantly in Finland, France, Greece, Italy, the Netherlands, Spain and, to a lesser extent, Belgium. The marginal effect of an increase in the spread on capital spending varies in strength from country to country but is particularly acute in Finland where a sustained 10 basis point increase in the spread over a 12 month period is associated with an almost 11 per cent decrease in sales of capital goods.

There is less predictive content in the finance mix variable. In Belgium and Italy past changes in the finance mix forecast changes in capital goods quite well; less so in Finland and Portugal. But again the finance mix variable fails the sum of coefficients test except in Italy. So Italy is the only country where both price-based and quantity-based financial information variables in the forecasting equation provide independent information for future movements of capital spending in a way that is consistent with the ACS model.

To check the robustness of the predictive ability of credit spreads, we repeated the forecasting exercise using the ECB-spread alongside the finance mix. As indicated earlier, the ECB-spread differs from the spread in that it is based on the cost of new loans only and uses the swap rate as the riskless rate. Overall, the results in Table 7 suggest that the predictive ability and the economic effect of the ECB-spread are somewhat weaker than those of the spread. In the case of Industrial Production in Italy and Retail Sales in France and the Netherlands, the ECB-spread has neither predictive power nor a systematic negative effect, whereas the spread does. The predictive power of the ECB-spread as measured by the exclusion restriction is also weaker for the Turnover of Capital Goods in Austria, France, and Germany. In contrast, the ECB-spread outperforms the spread as a predictor for Industrial Production in Belgium and Germany. For the Rate of Unemployment, there are merely minor changes in the performance of the two credit spreads in the ten countries of the EMU.

\section{An Alternative Spread Based on Bond Yields}

Up to now the credit spreads employed in the forecasting exercise have been based on the cost of borrowing from banks. We now introduce a credit spread based on bond yields. Following the work of Gilchrist and Zakrajšek (2012), Guender and Tolan (2017) employ monthly firm-level corporate data to design an aggregate bond yield spread that is meant to capture the risk premium in the corporate bond market in a number of European countries on the periphery and Germany at the centre. With the help of yields on zero coupon German government bonds, which are deemed safe, Guender and Tolan calculate the yield to maturity of a synthetic bond, a measure of the risk-free rate. The GZ-spread in country $a$ is defined as 


$$
G Z_{t}^{a}=\frac{1}{n} \sum_{j} R_{j t}^{\text {Corp }}-R_{j t}^{\text {risk-free }}
$$

where

$R_{j t}^{\text {Corp }}=$ the yield on corporate bond $j$ in period $t$

$R_{j t}^{\text {risk-free }}=$ yield on the synthetic "risk-free" bond $j$ in period $t .{ }^{37}$

$n=$ number of observations (individual corporate bonds) in period $t$.

Guender and Tolan document that the risk premium rises in all countries before and during the European-wide recessions and acts as a reliable signal for near term economic activity.

For a subset of the ten countries - Germany, Italy, Portugal and Spain - we examine the forecasting power of the GZ-spread and the finance mix, using the observations of the risk premium calculated by Guender and Tolan for the period 2004:02-2012:m08. The results of this exercise are shown in Table 8. Changes in the GZ-spread have impressive predictive power for Industrial Production and a significant impact on it in all countries but Spain. The results are a bit weaker for Retail Sales, where the GZ-spread performs best in Germany and Spain, and the Turnover of Capital Goods, where the GZ-spread does very well in Germany and Italy. Lagged changes in the bond spread correctly predict the direction of change in the Rate of Unemployment only in Italy. It is interesting to note that the sum of the coefficients on lags of the change in the bond spread has the correct negative sign in the forecasting equations for Industrial Production, Retail Sales, and the Turnover of Capital Goods in all four countries. In the subset of countries investigated the finance mix again does rather poorly as a predictor of economic activity. Only in two cases (Retail Sales in Spain and Capital Spending in Italy) does the finance mix predict the direction of change in economic activity correctly and to great effect. This is consistent with the results reported earlier for the 'spread' in Italy where changes in both the finance mix and the GZ-spread predict changes in capital spending in a way that is consistent with the theoretical framework of this paper. ${ }^{38}$

${ }^{37}$ The synthetic bond $j$ has the same underlying characteristics as the risky corporate bond $j$ (Term to maturity, coupon payments, etc.)

${ }^{38}$ A direct comparison to the results reported earlier is hampered by the shorter sample period for the forecasting equations based on the GZ-spread. The strong predictive ability and positive effect of the finance mix on Retail Sales in Spain may seem surprising given its lacklustre performance in the forecasting equations which included the 'spread' or 'ECB-spread'. However, changes in the finance mix variable do have impressive predictive ability and a strong positive effect on Retail Sales in Spain when paired with the 'spread' or the 'ECBspread' and estimated over the shorter sample period which ends in August 2012. This finding resonates in part with the observation of Ciccarelli et al. (2013) that a potent bank-lending channel of monetary policy was operative in the stressed countries at the height of the Global Financial Crisis. 
Table 8: The Effects of the GZ-Spread (Bond Yield Spread) and the Finance Mix on Measures of Economic Activity:

2004:02-2012:m08

\begin{tabular}{|c|c|c|c|c|c|c|c|c|c|c|c|c|}
\hline & \multicolumn{4}{|c|}{ Industrial Production } & \multicolumn{4}{|c|}{ Retail Sales } & \multicolumn{4}{|c|}{ Unemployment Rate } \\
\hline & Lags $(1, m, n)$ & $\bar{R}^{2}$ & $\mathrm{~F}$ [p-val] & SoC & $\operatorname{Lags}(1, m, n)$ & $\bar{R}^{2}$ & $\mathrm{~F}$ [p-val] & SoC & Lags $(1, m, n)$ & $\bar{R}^{2}$ & $\mathrm{~F}[\mathrm{p}-\mathrm{val}]$ & SoC \\
\hline Germany & $(12,12,12)$ & 0.95 & $\begin{array}{l}3.29^{*, * * *} \\
{[0.01]} \\
1.20 \\
{[0.30]}\end{array}$ & $\begin{array}{l}-23.44^{* * *} \\
(5.79) \\
-0.46 \\
(2 . .23)\end{array}$ & $(12,12,12)$ & 0.45 & $\begin{array}{l}1.96^{* * *} \\
{[0.04]} \\
0.72 \\
{[0.73]}\end{array}$ & $\begin{array}{l}-6.06^{* * *} \\
(2.46) \\
-2.89^{*} \\
(1.57)\end{array}$ & $(12,12,12)$ & 0.65 & $\begin{array}{l}0.67 \\
{[0.78]} \\
0.31 \\
{[0.99]}\end{array}$ & $\begin{array}{l}0.14 \\
(0.14) \\
\\
0.01 \\
(0.04)\end{array}$ \\
\hline Italy & $(12,12,12)$ & 0.95 & $\begin{array}{l}2.37^{* * * *} \\
{[0.01]} \\
0.87 \\
{[0.57]} \\
\end{array}$ & $\begin{array}{l}-10.49^{* * *} \\
(3.94) \\
0.51 \\
(4.01)\end{array}$ & $(12,12,12)$ & 0.75 & $\begin{array}{l}1.08 \\
{[0.39]} \\
0.78 \\
{[0.67]} \\
\end{array}$ & $\begin{array}{l}-1.99 \\
(1.26) \\
1.93 \\
(1.75)\end{array}$ & $(12,12,12)$ & 0.21 & $\begin{array}{l}1.89^{* *} \\
{[0.05]} \\
1.01 \\
{[0.44]}\end{array}$ & $\begin{array}{l}0.42^{\text {** }} \\
(0.19) \\
\\
-0.37 \\
(0.27) \\
\end{array}$ \\
\hline Portugal & $(12,12,12)$ & 0.61 & $\begin{array}{l}2.27^{* *} \\
{[0.02]} \\
1.18 \\
{[0.32]}\end{array}$ & $\begin{array}{l}-36.52^{* * *} \\
(9.82) \\
-2.91 \\
(4.12)\end{array}$ & $(12,12,12)$ & 0.75 & $\begin{array}{l}0.95 \\
{[0.51]} \\
1.03 \\
{[0.43]}\end{array}$ & $\begin{array}{l}-11.14^{* *} \\
(5.60) \\
4.06 \\
(2.98)\end{array}$ & $(12,12,12)$ & 0.21 & $\begin{array}{l}1.14 \\
{[0.34]} \\
1.51 \\
{[0.14]}\end{array}$ & $\begin{array}{l}0.54 \\
(0.60) \\
\\
0.12 \\
(0.21)\end{array}$ \\
\hline Spain & $(12,12,12)$ & 0.93 & $\begin{array}{l}1.53 \\
{[0.14]} \\
0.81 \\
{[0.64]}\end{array}$ & $\begin{array}{l}-6.75^{*} \\
(3.57) \\
1.46 \\
(3.17)\end{array}$ & $(12,12,12)$ & 0.93 & $\begin{array}{l}1.96^{* *} \\
{[0.04]} \\
2.52^{* * *} \\
{[0.01]}\end{array}$ & $\begin{array}{l}-5.48^{* * *} \\
(1.73) \\
44.20^{* * *} \\
(9.01)\end{array}$ & $(12,12,12)$ & 0.82 & $\begin{array}{l}0.94 \\
{[0.51]} \\
0.85 \\
{[0.60]}\end{array}$ & $\begin{array}{l}0.04 \\
(0.17) \\
\\
-1.22 \\
(0.88)\end{array}$ \\
\hline
\end{tabular}


Table 8: The Effects of the GZ-Spread (Bond Yield Spread) and the Finance Mix on Measures of Economic Activity: 2004:02-2012:m08 (cont.)

\begin{tabular}{|l|l|l|l|l|}
\hline & \multicolumn{3}{|c|}{ Turnover of Capital Goods } \\
\hline & Lags(1,m,n) & \multicolumn{1}{|c|}{$\bar{R}^{2}$} & F [p-val] & SoC \\
\hline Germany & $(12,12,12)$ & 0.90 & $3.16^{* * * *}$ & $-42.62^{* * *}$ \\
& & & {$[0.01]$} & $(11.87)$ \\
& & & 0.73 & -3.30 \\
& & & {$[0.71]$} & $(4.56)$ \\
\hline Italy & $(12,12,12)$ & 0.95 & $3.33^{* * * *}$ & $-52.67^{* * *}$ \\
& & & {$[0.01]$} & $(11.25)$ \\
& & & $2.35^{* * *}$ & $45.10^{* * * *}$ \\
& & & {$[0.01]$} & $(13.64)$ \\
\hline Portugal & $(12,12,12)$ & 0.33 & 0.85 & -4.28 \\
& & & {$[0.60]$} & $(23.30)$ \\
& & & 1.45 & -10.02 \\
& & & {$[0.16]$} & $(19.66)$ \\
\hline Spain & & & 1.27 & $-23.29^{* * *}$ \\
& & 0.78 & {$[0.25]$} & $(10.74)$ \\
& & & & 15.38 \\
& & & 0.32 & $(33.84)$ \\
\hline
\end{tabular}

Notes:

1. The turnover of the capital goods series for Portugal is clearly stationary. Hence the log of this series appears in the regression specification.

2. Estimated specification of the regression equation (unless indicated otherwise):

$\Delta y_{t}=a_{0}+\sum_{i=1}^{l} a_{i} \Delta y_{t-i}+\sum_{i=1}^{m} b_{i} \Delta E C B s p r_{t-i}+\sum_{i=1}^{n} c_{i} \Delta \operatorname{mix}_{t-i}+e_{t}$

where $\Delta y=$ first difference of an annualized measure of economic activity, $\Delta E C B s p r=$ change of the weighted lending spread between the MIR rate for new NFC (non-financial corporation) loans and the swap rate (maturity adjusted).

$\Delta$ mix $=\Delta\left(\frac{\text { Loans to } N F C}{\text { Loans to NFC }+ \text { Securities issued by NFC }}\right)$

$\mathrm{F}=\mathrm{F}$-statistic of the null hypothesis that $m(n)$ lags of the change in the ECB spread (finance mix) are jointly insignificant. The number in brackets is the probability that the null hypothesis can be rejected (p-value). SoC $=\mathrm{t}$-test of the hypothesis that the sum of the coefficients $b_{i}\left(c_{i}\right) i=1,2, \ldots m(n)$ on $m(n)$ lags of the ECB spread (finance mix) equals zero. The number reported at the top of the cell is the sum of the coefficients. The number below in parentheses is the standard error. All variables were tested for non-stationarity. Non-stationary variables have been differenced.

\# Estimated specification includes a deterministic time trend.

\section{Conclusions}

In a recent paper, Adrian, Colla, and Shin (2013) propose a model of the credit market to document a few stylized facts about the behaviour of the prices and quantities of credit, the size of the banking sector relative to the bond market, and leverage as market sentiment changes. Looking at macro and micro-level US data, they find a good deal of empirical support for rising credit spreads, a substitution of bonds for bank finance, and deleveraging during the Global Financial Crisis.

An important prediction of their theoretical framework is that an increase in default risk causes the credit spread to rise and the bond market to expand at the expense of the banking sector. This paper examines this hypothesis and traces its implications for real economic activity in ten member states of the euro area over the period 2003:1-2016:3. To implement the empirical test, we construct three credit spreads and one quantity-based finance mix. 
The difference between the cost of borrowing and a short-term money market rate rose unambiguously during the two recessions in all the countries of the EMU included in this study. The 'spread' had, however, not risen substantially in a single country before the onset of the first recession, a clear indication that the financial markets were caught unaware of the oncoming financial and economic turmoil. In the interval between the two recessions the spread continued to rise on the southern fringe of the EMU, in Greece, Portugal, and Spain. By comparison, movements in the finance mix variable were less systematic.

The empirical results show that credit spreads provide a more reliable signal about nearterm economic activity than the composition of external finance. A presumed link between changes in the composition of external finance, which the bank lending view interprets as loan supply constraints, and changes in real economic activity does not appear to exist. These findings tend to support Adrian, Colla, and Shin's basic contention that "[i]n our model, the impact on real economic activity comes from the spike in risk premiums rather than contraction in the total quantity of credit" (p. 49).

Overall the findings suggest, however, that the forecasting performance of credit spreads over a short horizon in the ten EMU member states is rather spotty. This assessment is based on the uneven performance of the credit spreads. The 'spread' is arguably a better predictor of real economic activity than the ECB-spread, which is the difference between the cost of taking out new loans and the swap rate. Even so, the 'spread' fails to predict consistently across either a range of monthly economic indicators or across countries. The strongest evidence in favour of the predictive ability of credit spreads comes from the corporate bond market. A risk premium extracted from corporate bond yields predicts Industrial Production, Retail Sales, and Turnover of Capital Goods fairly well in Southern Europe and Germany.

On balance, the size of the financial sector is not tied to the near-term forecasting performance of financial indicators. Neither the spreads nor the finance mix variable have greater predictive ability in the Netherlands or Belgium, where the financial sector accounts for a far greater share of total GDP, than in countries with smaller financial sectors such as Finland and Greece.

Examining developments in credit markets in the euro area over the past 15 years leads to the conclusion that these markets have evolved unevenly. In the Netherlands, and particularly in Finland and France, the bond market was an important secondary source of credit long before the Global Financial Crisis. By contrast, in Austria, Belgium, Germany, Italy, and Portugal, the bond market's relative share of the credit market gradually increased over the sample period whereas it remained very small in Greece and Spain. The empirical study finds mixed evidence for the substitution hypothesis of bond finance for bank credit during recessions in the Euro area. While there is no evidence at all for it during the first recession, there is selective evidence that bond issuance expanded and bank loans contracted during the second recession particularly in France and Italy and to a lesser extent in Greece and Spain. 
Further investigation of the quantitative importance of bond finance versus bank finance for real economic activity in the EMU is warranted. One obvious limitation of the current study is that it is based entirely on macro-level data. A micro-level data analysis of the composition of external finance in the EMU along the lines of Becker and Ivashina (2014) and ACS (2013) would shed further light on whether the bond markets of Europe have matured to be viable alternative sources of finance at the firm level, particularly in times of economic stress. 


\section{References}

ADRIAN, T. AND H. S. SHIN. "Money, Liquidity, and Monetary Policy," American Economic Review 99 (2009), 600-605.

ADRIAN, T., P. COLLA AND H. S. SHIN. "Which Financial Frictions? Parsing the Evidence from the Financial Crisis of 2007 to 2009," NBER Macroeconomics Annual 201227 (2013), 159-214.

AUSTRIAN NATIONAL BANK, Financial Stability Report 26, 2013.

BANCO DE ESPAÑA. "Euro Area Corporate Debt Issuance during the Crisis," Economic Bulletin December (2015), 23-31.

BASSETT, W., M. B. CHOSAK, J. DRISCOL AND E. ZAKRAJŠEK. "Changes in Bank Lending Standards and the Macroeconomy," Journal of Monetary Economics 62 (2014), 23-40.

BECKER, B. AND V. IVASHINA. "Cyclicality of Credit Supply: Firm Level Evidence," Journal of Monetary Economics, 62 (2014), 76-93.

BERNANKE, B. AND M. GERTLER. "Agency Costs, Net Worth, and Business Fluctuations," American Economic Review 79 (1989), 14-31.

BERNANKE B., M. GERTLER AND S. GILCHRIST. "The Financial Accelerator and the Flight to Quality," Review of Economics and Statistic 78 (1996), 1-15.

BERNANKE B., M. GERTLER AND S. GILCHRIST. "The Financial Accelerator in a Quantitative Business Cycle Framework." In: Handbook of Macroeconomics vol. 1C, Elsevier, Amsterdam, 1999, 1341-1393.

BORIO, C. AND H. ZHU. "Capital Regulation, Risk Taking and Monetary Policy: a Misssing Link in the Transmission Mechanism?" Journal of Financial Stability 8 (2012), 236-251.

CECCHETTI, S., M. KOHLER AND C. UPPER. "Financial crises and economic activity," Proceedings - Economic Policy Symposium - Jackson Hole, Federal Reserve Bank of Kansas City (2009), 89-135.

CICARELlI, M., A. MADDALONI AND J. PEYDRO. "Heterogeneous Transmission Mechanism: Monetary Policy and Financial Fragility in the Eurozone," Economic Policy 28 (2013), 459-512.

CLAESSENS, S., M. A. KOSE AND M. TERRONES. "What Happens during Recessions, Crunches, and Busts," Economic Policy 24 (2009), 653-700.

CURDIA, V. AND M. WOODFORD. "Credit Spreads and Monetary Policy," Journal of Money, Credit and Banking, 42 (2010), 3-35.

DELL'ARICCIA, G., L. LAEVEN AND R. MARQUEZ. "Real Interest Rates, Leverage, and Bank Risk-Taking,” Journal of Economic Theory 149 (2014), 65-99. 
DE FIORE F. AND H. UHLIG. "Bank Finance versus Bond Finance," Journal of Money, Credit, and Banking 43 (2011), 1399-1421.

DE FIORE F. AND H. UHLIG. "Corporate Debt Structure and the Financial Crisis," NBER Working Paper 20730 (2014).

DEUTSCHE BUNDESBANK. "Recent Developments in Loans to Euro-Area Non-Financial Corporations," Monthly Report, (2015), 15-39.

EUROPEAN CENTRAL BANK. Report on Financial Structure, 2015.

FRIEDMAN B. AND K. KUTTNER. "Money, Income, Prices, and Interest Rates," American Economic Review 82 (1992), 472-492.

GERTLER, M. AND C. S. LOWN. "The Information in the High-Yield Bond Spread for the Business Cycle: Evidence And Some Implications," Oxford Review of Economic Policy 15 (1999), 132-150.

GILCHRIST S. AND E. ZAKRAJŠEK. "Credit Spreads and Business Cycle Fluctuations," American Economic Review 102 (2012), 1692-1720.

GREENWOOD, R. AND D. SCHARFSTEIN. "The Growth of Finance," Journal of Economic Perspectives 27 (2013), 3-27.

GUENDER, A. AND B. TOLAN. "The Predictive Ability of a Risk-Adjusted Yield Spread for Economic Activity in Europe," Empirica 44 (2017), 1-27.

JIMÉNEZ, G, S. ONGENA, J.-L PEYDRÓ AND J. SAURINA. "Credit Supply and Monetary Policy: Identifying the Bank Balance-Sheet Channel with Loan Applications. "American Economic Review 102 (2012), 2301-2326.

KASHYAP, A. AND J. STEIN. "What Do a Million Observations on Banks Say about the Transmission of Monetary Policy?" American Economic Review 90 (2000), 407-428.

KASHYAP, A., J. STEIN AND D. WILCOX. "Monetary Policy and Credit Conditions: Evidence from the Composition of External Finance," American Economic Review 83 (1993), 78-98.

KAYA, O. AND T. MEYER. "Corporate Bond Issuance in Europe," EU Monitor, Deutsche Bank Research, January $31^{\text {st }}(2013)$.

KAYA, O. AND T. MEYER. "Tight Bank Lending, Lush Bond Market, Current Issues, Global Financial Markets, Deutsche Bank Research, April 15 ${ }^{\text {th }}$ (2014).

KRISHNAMURTHY, A. AND T. MUIR. "Credit Spreads and the Severity of Financial Crises," Unpublished paper, (2015).

NEWEY, W. AND K. WEST. "A Simple Positive Semi-Definite Heteroscedasticity and Autocorrelation Consistent Covariance Matrix," Econometrica 55 (1987), 703-708.

NG, S. AND J. WRIGHT. "Facts and Challenges from the Great Recession for Forecasting and Macroeconomic Modeling, " Journal of Economic Literature 51 (2013), 11201154. 
OLINER, S. AND G. RUDEBUSCH. "Monetary Policy and Credit Conditions: Evidence from the Composition of External Finance: Comment," American Economic Review 86 (1996), 300-309.

PHILIPPON, T. “The Bond Market's Q, " Quarterly Journal of Economics 124 (2009), 1011-1156.

REINHART, C. AND K. ROGOFF. This Time is Different: Eight Centuries of Financial Folly. Princeton, NJ: Princeton University Press, 2009.

ROMER, C. AND D. ROMER. "New Evidence on the Impact of Financial Crises in Advanced Countries," NBER Working Paper 21021 (2015).

SCHULARICK, M. AND A. TAYLOR. "Credit Booms Gone Bust: Monetary Policy, Leverage Cycles, and Financial Crises, 1870-2008”, American Economic Review 102 (2012), 1029-1061.

STEIN, J. "Incorporating Financial Stability Considerations into a Monetary Policy Framework," Remarks at the International Research Forum on Monetary Policy, Washington, DC, 2014.

STIGLITZ, J. AND A. WEISS. "Credit Rationing in Markets with Imperfect Information," American Economic Review 71 (1981), 393-410.

STOCK, J. AND M. WATSON. "Forecasting Output and Inflation: the Role of Asset Prices," Journal of Economic Literature 41 (2003), 788-829.

VANHOOSE, D. "Theories of Bank Behavior under Capital Regulation," Journal of Banking and Finance, 31, (2007), 3680-3697. 


\section{Working Papers of Eesti Pank 2017}

No 1

Barry Eichengreen. Ragnar Nurkse and the international financial architecture

No 2

Juan Carlos Cuestas, Merike Kukk. Asymmetries in the interaction between housing prices and housing credit in Estonia

No 3

Gregory Levieuge, Yannick Lucotte, Florian Pradines-Jobet. Central banks' preferences and banking sector vulnerability

No 4

Jaanika Meriküll, Tairi Rõõm. The financial fragility of Estonian households: evidence from stress tests on the HFCS microdata

No 5

Konstantin A. Kholodilin, Aleksei Netsunajev. Crimea and punishment: the impact of sanctions on Russian and European economies 